\title{
27. CRETACEOUS CALCAREOUS NANNOFOSSILS FROM DEEP SEA DRILLING PROJECT LEG 77, SOUTHEAST GULF OF MEXICO ${ }^{1}$
}

\author{
David K. Watkins, Department of Geology, Florida State University, Tallahassee, Florida \\ and \\ Jay L. Bowdler, Union Oil Company of California, Houston, Texas
}

\begin{abstract}
Five of the six sites drilled during Leg 77 of the Deep Sea Drilling Project yielded Cretaceous sediments. Two of these sites, 535 and 540, form a composite section that spans the upper Berriasian through most of the Cenomanian. Olive black marly limestones in this interval yield relatively rich, well-preserved nannofossil assemblages that allow biostratigraphic subdivision of the sequence. This composite section provides important information on the Early Cretaceous history of the Gulf of Mexico, as well as additional information on tropical Lower Cretaceous nannofossil assemblages. The post-Cenomanian nannofossil (and sedimentary) record is limited to a thin, condensed section of Santonian through lower Maestrichtian pelagic sediments at one site (538) and is absent or represented by redeposited material at the other sites. Two new genera, Perchnielsenella and Darwinilithus, are described. Two new taxa, Darwinilithus pentarhethum and Lithraphidites acutum ssp. eccentricum, are described; and two new combinations, Rhagodiscus reightonensis and Perchnielsenella stradneri, are proposed.
\end{abstract}

\section{INTRODUCTION}

Drilling on Leg 77 of the Deep Sea Drilling Project was designed to investigate the early history of the deep Gulf of Mexico with the following two specific objectives: to examine the Tertiary and (especially) Mesozoic sedimentary history of the deep Gulf and to examine the nature of the basement complex that underlies this portion of the Gulf (Fig. 1). In order to accomplish these objectives, two distinctly different types of sites were drilled: "basin" and "basement" sites. Five of the six sites drilled yielded Cretaceous sediments.

The basin sites were drilled to investigate the history of sedimentary basin fill in the deep Gulf. Two sites (535 and 540) were drilled on an erosional slope at the western end of the Straits of Florida where seismic evidence had indicated a thick, pre-middle Cretaceous section within the reach of the drill string of the Glomar Challenger. These sites were offset (Fig. 1) so that one hole (535) was spudded in near the stratigraphic level at which the other hole (540) reached total depth. Because of this arrangement, the sediments recovered from both sites yield a fairly complete composite section spanning the late Berriasian through the middle Cenomanian. The top of this sequence (middle Cenomanian) had been drilled previously during Leg 10 (Worzel, Bryant, et al., 1973). The nannofossils recovered from these two basin sites provide biostratigraphic control for the analysis of this long sequence. In addition, the composite section of Sites 535 and 540 provides a relatively complete record of the tropical Early Cretaceous nannofloras of the Gulf of Mexico.

Basement Sites 536, 537, and 538 (Fig. 1) were drilled primarily to investigate the nature of the basement com-

\footnotetext{
${ }^{1}$ Buffler, R. T., Schlager, W., et al., Init. Repts. DSDP, 77: Washington (U.S. Govt. Printing Office).
}

plex. These sites were located on high-standing basement blocks that lie to the west of the Straits of Florida. The thin sedimentary cover overlying these blocks yielded a very discontinuous record of Cretaceous sedimentation. Nannofossils are largely restricted to post-Barremian strata at these sites. The post-Barremian sedimentary record largely consists of thin, pelagic, biogenic deposits commonly separated by omission surfaces. Nannofossils typically are abundant and well preserved in these deposits. The basement sites are of special interest because they yielded the only significant amount of Upper Cretaceous sediment recovered on Leg 77.

The species considered in this chapter are listed alphabetically by species epithets in the Appendix at the end of this chapter. Most of the bibliographic references for these taxa are presented in Loeblich and Tappan (1966, $1968,1969,1970 \mathrm{a}, 1970 \mathrm{~b}, 1971,1973)$ and in van Heck (1979a, 1979b, 1980a, 1980b, 1981a, 1981b, 1982a, 1982b). Any references not found therein are listed in the references of this chapter.

\section{METHODS AND PROCEDURES}

The overall abundance of calcareous nannofossils in the Cretaceous material recovered from Leg 77 is quite variable. This is true especially for the pre-Turonian sediments recovered. Nannofossils, as a sedimentary component, may comprise anywhere from 0 to $80 \%$ of the rock. All abundances of nannofossils (as a sedimentary component) were estimated from smear slides of raw sediment using the following criteria: A, abundant (nannofossils comprise more than $15 \%$ of the sediment); C, common (nannofossils comprise $5-15 \%$ of the sediment); $F$, few (nannofossils comprise $1-5 \%$ of the sediment); $R$, rare (nannofossils comprise less than $1 \%$ of the sediment); EB, essentially barren (nannofossils significantly less than $1 \%$ of the sediment, typically with fewer than 10 specimens per 100 fields of view at $1560 \times$ ); B, barren (no nannofossils observed in 100 fields of view at $1560 \times)$.

Much of the limestone recovered from the Cretaceous of Leg 77 is barren of nannofossils. Although much of this material has been examined, barren samples are reported only on the range charts when all of the samples from a given core are barren and that core occurs in a sequence that has nannofossils in other cores. Thus, for example, the 


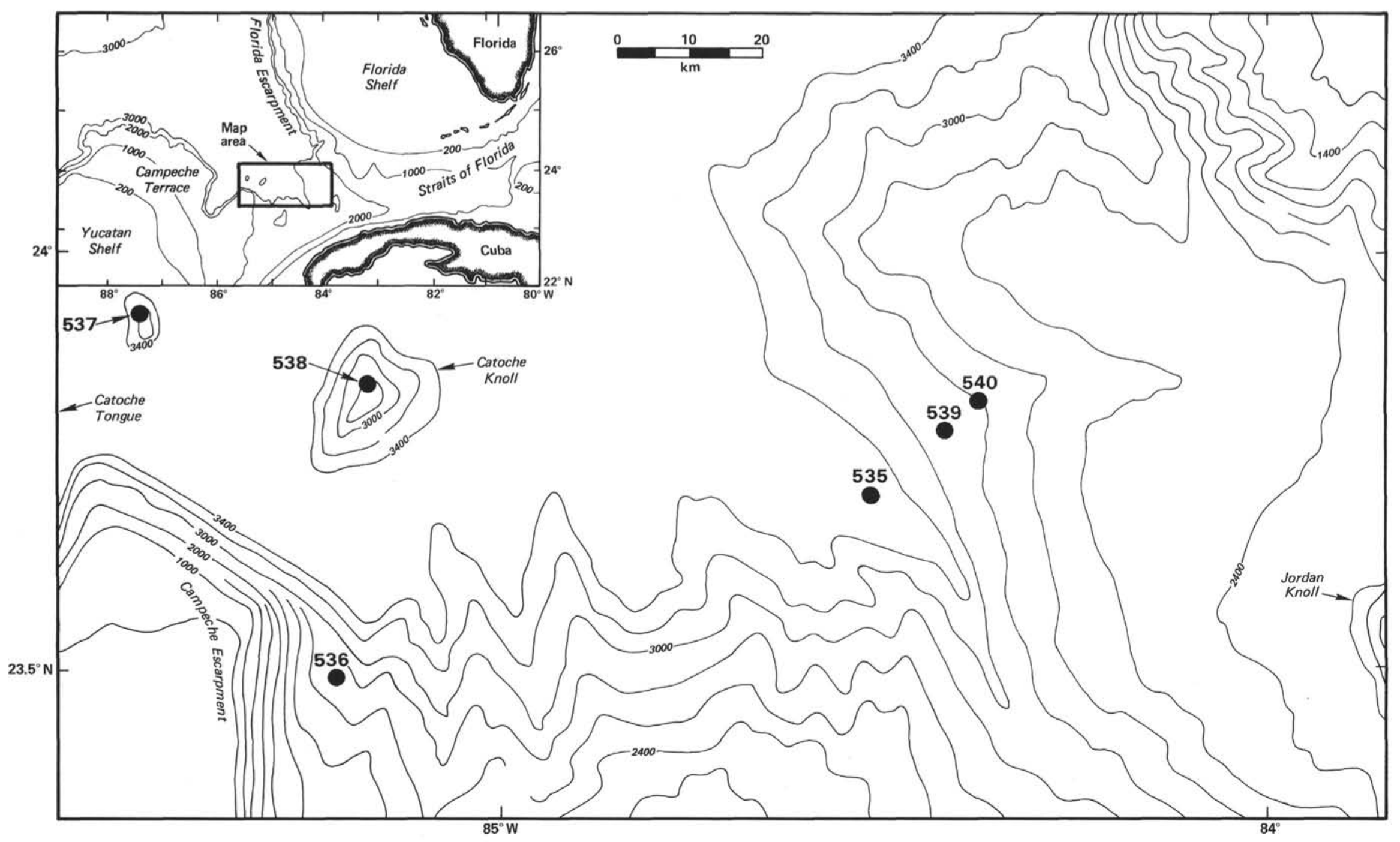

Figure 1. Site locations, Leg 77. 
barren, skeletal limestones of Site 537 have not been reported on a range chart because the entire interval is barren.

Preservation of nannofossils in the pre-Turonian sections at Sites 535 and 540 is highly controlled by lithology. Generally, the biostratigraphically most useful assemblages were obtained from olive gray or olive black marly limestones. These marly limestones are generally quite thin (often less than $5 \mathrm{~cm}$ ), and there are seldom more than one or two of these horizons per core. Assemblages from the surrounding lighter-colored limestones are sparse, poorly preserved, and of limited biostratigraphic utility. Thus, the assemblages reported on the range charts are generally those that come from darker marly limestones. Although samples from the lighter-colored limestones were examined, the assemblages from these samples are only reported when they are of biostratigraphic significance.

The abundances of individual nannofossil species in a given sample, in all cases, were estimated from light microscopic examination of smear slides made directly from raw sediment. The majority of Cretaceous samples also were concentrated by gravitational settling techniques for additional light microscopic and/or electron microscopic examination. Any species found in these concentrated samples that were not observed on the smear slide have been listed as " $R$ " (rare) on the range charts. Estimations of the relative abundances of individual species in a given sample were made by the following criteria: $\mathrm{V}$, very abundant (more than 10 specimens per field of view at $1560 \times$ ); A, abundant ( 1 to 10 specimens per field of view at $1560 \times$ ); $C$, common ( 1 specimen per $2-10$ fields of view at $1560 \times)$; $F$, few ( 1 specimen per 11-100 fields of view at $1560 \times)$; R, rare (1 specimen per 101-1000 fields of view at $1560 \times$ ).

This system is essentially that proposed by Hay (1970), except that the magnification is increased from $1000 \times$ to $1560 \times$. The increase in magnification was warranted because smaller species often were misidentified or their abundance underestimated at the lower magnification.

A qualitative analysis of the state of preservation of the nannofossils observed in each sample was made using the following criteria: G, good (specimens exhibit little or no secondary alteration); M, moderate (specimens exhibit the effects of secondary alteration due to etching and/or overgrowth; identification of species typically not impaired); P, poor (specimens exhibit profound effects of secondary alteration due to etching and/or overgrowth; identification of species impaired but often still possible).

These ratings are based on the "average" state of preservation of the nannofossils examined on the smear slides because typically there is a considerable range of variation in the state of preservation in a given sample. This is especially true of the assemblages in Lower Cretaceous sediments recovered on Leg 77.

Samples were prepared for scanning electron microscopy following the procedures outlined in Wise and Kelts (1972). Samples were examined and specimens photographed using a Cambridge IV Stereoscan Scanning Electron Microscope.

\section{BIOSTRATIGRAPHIC ZONATION}

No single published zonation scheme combined ease of application and a relatively high degree of biostratigraphic resolution that was desired for the zonation of all the Cretaceous material recovered during Leg 77. For this reason, a combination of three published zonations has been used in this chapter (Fig. 2).

The interval from the Turonian through the Maestrichtian has been biostratigraphically subdivided following the zonation of Sissingh (1977). The age assignments of some nannofossil biohorizons have been adjusted in accordance with information in Perch-Nielsen (1979). The interval from the late Aptian through the Cenomanian is zoned following Manivit et al (1977). Age assignments for nannofossil biohorizons in this "mid"Cretaceous interval have been adjusted in accordance with information from Perch-Nielsen (1979) and, with one exception, Manivit (1981). The placement of the extinction of Hayesites albiensis at the Albian/Cenomanian boundary by Manivit (1981) has not been followed.
This biohorizon occurs at leg 77, Sites 538 and 540. At both sites, this extinction occurs within the Planomalina buxtorfi foraminiferal Zone of latest Albian age. In addition, at Site $540, H$. albiensis has its highest occurrence in a sample approximately $65 \mathrm{~cm}$ below an ammonite-bearing horizon dated as late Albian (dispar and/or substuderi zones; Young, this volume). The latest Albian assignment for this biohorizon occurs with the extinction level of $H$. albiensis in Thierstein (1976), Manivit et al. (1977), and Perch-Nielsen (1979). It should be noted that the zonal names used herein will not necessarily coincide with those used in the site chapters for strata of post-Barremian age.

Difficulty arose in attempting to use published zonations for the Berriasian through lower Aptian sediments recovered on Leg 77 . This problem was especially acute with regard to the Valanginian and Hauterivian nannofossil record. No published zonation provided both the ease of applicability and the degree of resolution desired. This general inadequacy is due, in large part, to the paucity of well-studied sections of nannofossil-bearing Lower Cretaceous sediment (relative to the Upper Cretaceous and, especially, the Cenozoic). The zonation of Thierstein $(1971,1973)$ offered the most easily utilized scheme for the Berriasian through the lower Aptian strata recovered on Leg 77, because it is largely based upon tropical (Tethyan) nannofossil assemblages. In order to increase the degree of resolution of this zonation, three additional, intermediate biohorizons were used: the first occurrence of Reinhardtites fenestratus, the first occurrence of Cretarhabdus loriei, and the extinction of Cruciellipsis cuvillieri.

The oldest of these biohorizons is the first occurrence of Reinhardtites fenestratus. Thierstein (1976) placed the first occurrence of $R$. fenestratus near the top of the Berriasian, a placement largely followed by Perch-Nielsen (1979). At Site 535, R. fenestratus first occurs in Section 535-75-1. This is within one core of the placement of the Berriasian/Valanginian boundary based on calpionellid biostratigraphy (Premoli Silva and McNulty, this volume). The occurrence of this datum at Site 535 in conjunction with the published ranges indicates that the first occurrence of $R$. fenestratus may be a useful horizon for approximating the Berriasian/Valanginian boundary. More data need to be accumulated on the distribution of this taxon to test the validity of this age assignment.

The next biohorizon used was the first occurrence of Cretarhabdus loriei $(=$ Cretarhabdus striatus Stradner of some authors). Sissingh (1977) utilized this biohorizon as the indicator for the base of the $C$. loriei Zone. The $C$. loriei Zone, as defined by Sissingh (1977), could not be recognized in Leg 77 material because the marker species for the top of the zone (Speetonia colligata) was sporadic in its occurrence and had an anomalously old extinction (i.e., a local, as opposed to absolute, extinction) at Site 535. Both Sissingh (1977) and Perch-Nielsen (1979) place the first occurrence of $C$. loriei approximately at the Valanginian/Hauterivian boundary. This placement is followed in this chapter. Perch-Nielsen (1979) also noted that the first occurrence of Chiastozygus 


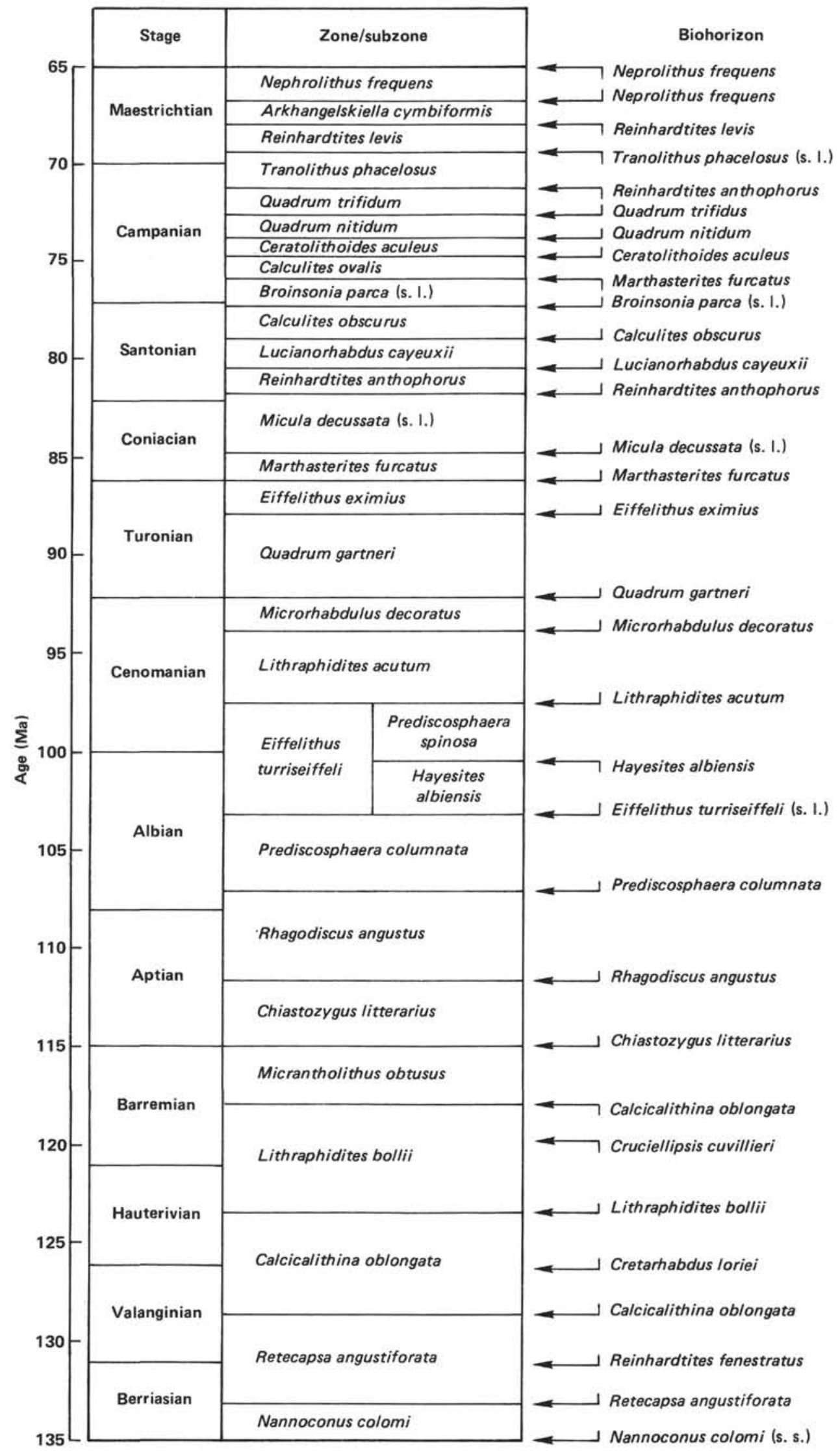

Figure 2. Biostratigraphic zonation used for Cretactous nannofossil assemblages of Leg 77. See text for sources of zonation and biohorizons. 
striatus approximately coincides with the first occurrence of Cretarhabdus loriei. The last occurrence of Chiastozygus striatus, during the late Hauterivian, also was used as a datum by Perch-Nielsen (1979). Neither of the Chiastozygus striatus biohorizons could be utilized with Leg 77 material as this species occurs too infrequently to yield a reliable first or last occurrence, suggesting that this species is only biostratigraphically useful for boreal assemblages.

The youngest intermediate biohorizon that was utilized is the last occurrence of Cruciellipsis cuvillieri. This biohorizon has been used by Roth $(1973,1978)$ as a zonal indicator for the top of his $C$. cuvillieri Zone. Thierstein (1976) recognized this biohorizon and concurred with Roth $(1973,1978)$ in its placement in the late Hauterivian. This age assignment agrees with that of PerchNielsen (1979) and is followed in this chapter. The placement of this biohorizon, as well as that for the other intermediate biohorizons, is illustrated in Figure 2.

\section{SITE SUMMARIES}

\section{Site $535\left(23^{\circ} 42.48^{\prime} \mathrm{N}, 8^{\circ} 30.97^{\prime} \mathrm{W}\right)$}

This was the first of two sites drilled to investigate the thick sedimentary section lying stratigraphically below the seismically prominent middle Cretaceous unconformity (MCU). Specifically, Hole 535 penetrated the older portion of this pre-middle Cretaceous sequence, whereas Hole 540 penetrated the younger portion of the sequence. The Cretaceous section recovered at Site 535 includes the interval from Sample 535-17,CC through Core 79 (terminal depth). In general, the sediments in this interval exhibit varying degrees of cyclicity, with alternations between light-colored and dark-colored lithologies that include laminated limestones; bioturbated limestones (predominantly light colored); massive, ammonite-bearing limestones (light colored); and (dark) marly limestones and (rarely) shale.

The lithologic variation in this sequence imposed a strong control over nannofossil abundance and preservation. Light-colored limestones are generally barren or essentially barren of nannofossils. The high carbonate content (typically over $85 \%$, see Site Chapter 535 , this volume) of these limestones promoted diagenesis that was strong enough to destroy most or all of the nannofossil material that may have been present. Dark-colored limestones, with a somewhat lower carbonate content, typically have sparse (rare to few) assemblages that are generally poorly preserved. The dark marly limestones provide the most abundant and best preserved assemblages in this stratigraphic interval. The higher clay content of these marly limestones apparently aided in the preservation of good nannofossil assemblages. Other frequent components of these marly limestones include framboidal pyrite, dolomite rhombs, and organic material. The hydrocarbon generation potential (Site Chapter 535, this volume), the degree of "darkness," and nannofossil abundance and preservation seem to covary in the Cretaceous of Site 535, with the darkest sediments having the highest potential for hydrocarbon generation and the most abundant and well-preserved nannofloras. The distribution of nannofossils for the Cretaceous is illustrated in Table 1.

Albian nannofossil assemblages occur from Sample 535-17,CC through Section 535-42-5. Sediments in this interval consist largely of laminated, gray limestones. Ripple cross-laminations are evident in Cores 535-18 through 535-28 and Cores 535-38 through 535-41. These ripple cross-beds are composed of packstones and/or grainstones containing pellets and other calcareous organic debris derived from nearby carbonate platforms (site chapter, Site 535, this volume). The large-scale influx of shallow-water debris seems to have completely masked the majority of the pelagic sedimentary input, including nannofossils. Specimens of scaphitid, hamitid, and acanthocerid ammonites from this interval indicate that this sequence is late Albian (Sample 535-45, CC ?) to middle Cenomanian (Core 31; Young, this volume). Nannofossil assemblages from this interval indicate an Albian age (Prediscosphaera columnata Zone). With two exceptions, however, the nannofossil assemblages recovered are extremely sparse and poorly preserved. In Cores 535-35 and 535-42, however, the amount of detrital carbonate decreases and finer-grained material dominates the sediment. Samples from these two cores contain more abundant and better-preserved nannofloras of the Prediscosphaera columnata Zone. Although the nannofossils in Core 42 could be in situ pelagic deposits (see Paleontological Synthesis, this volume), the absence of Eiffelithus turriseiffeli s.l. and other Cenomanian nannofossils, such as Lithraphidites acutum and Crucicribrum anglicum, in samples from Core 535-35 strongly implies that these nannofloras are part of the reworked sedimentary component rather than the normal pelagic component. At present, large-scale reworking of nannofossil assemblages seems to be restricted to the interval above Core 535-43.

Cores 535-43 through 535-47 contain at least three nannofossil zones. Cores 535-43 and 535-44 contain olive black, marly limestones with rich, well-preserved nannofloras of the Rhagodiscus angustus Zone (late Aptian to early Albian). The presence of Nannoconus kamptneri with Nannoconus quadriangulus in Section 535-44-2 implies the lower portion of the Rhagodiscus angustus Zone (late Aptian) (Perch-Nielsen, 1979, fig. 20). This age agrees with the assignment of this strata to the Hedbergella gorbachikae foraminiferal Zone (Premoli Silva and McNulty, this volume). Assemblages in Cores 53545 and 535-46 are not as rich or well preserved as those in the overlying two cores. Samples from the approximately $30 \mathrm{~cm}$ of limestone and ammonite-bearing limestone drilling breccia in Core 535-45 were essentially barren of nannofossils, with only poorly preserved, longranging forms present. Core 535-46 yields sparse assemblages assignable to the Chiastozygus litterarius Zone (early Aptian). Assemblages in Core 535-46 are highly dominated by nannoconids, with other nannofossils sparse and moderately to poorly preserved due to etching. The degree of nannoconid dominance is, at least in part, due to the diagenetic dissolution of other forms in response to the high carbonate content in this interval. Core 53547 is judged to be from above the level of extinction of 
Table 1. Distribution of Early Cretaceous nannofossils, Hole 535.

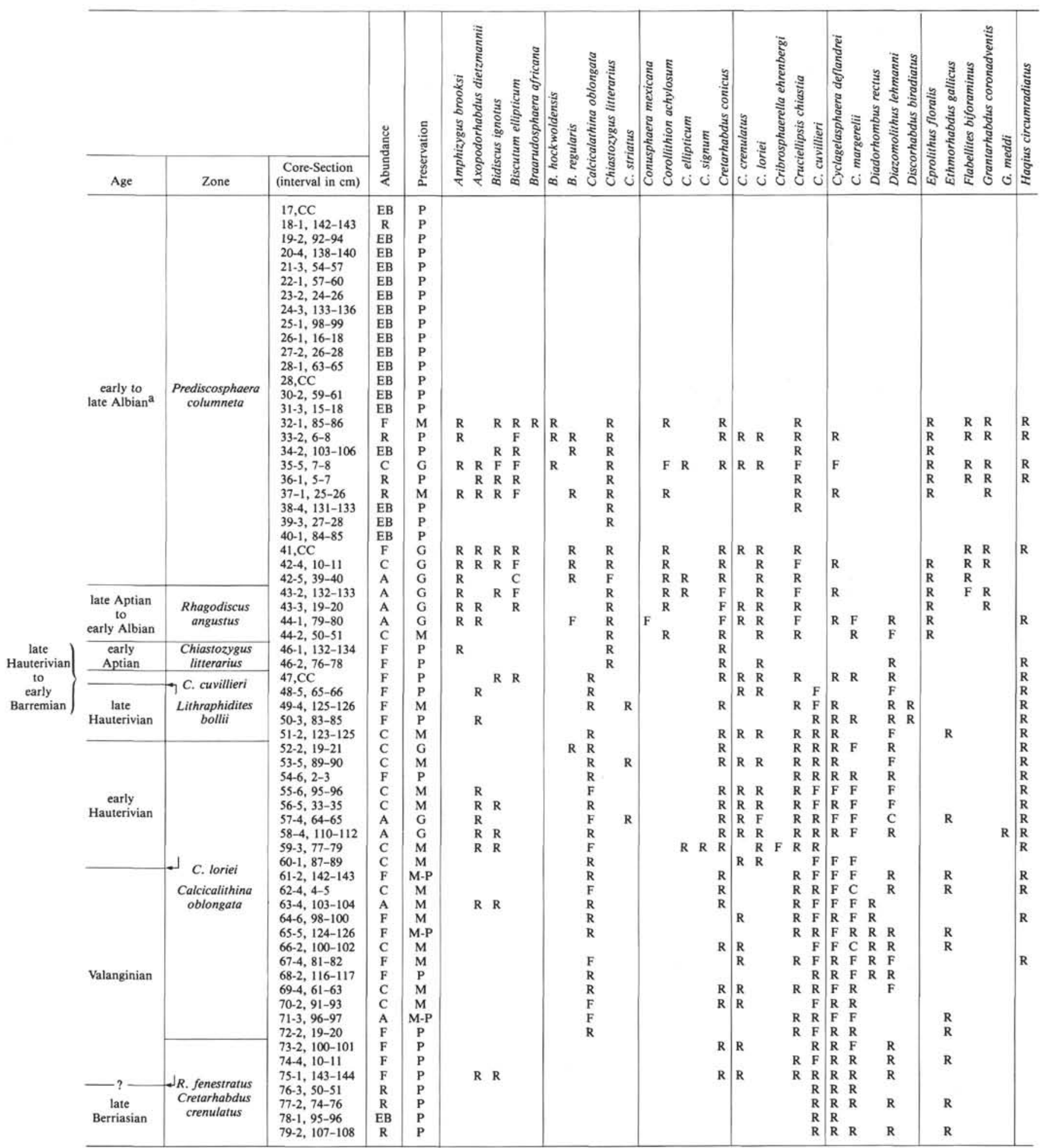

Note: $\mathrm{A}=$ abundant, $\mathrm{C}=$ common, $\mathrm{F}=$ few, $\mathrm{R}=$ rare; $\mathrm{EB}=$ essentially barren, $\mathrm{B}=$ barren, $\mathrm{G}=$ good, $\mathrm{M}=$ moderate, $\mathrm{P}=$ poor; see text for further explanation Note: $\mathrm{A}=$ abundant, $\mathrm{C}=$ common, $\mathrm{F}=$ few, $\mathrm{R}=$ rare; $\mathrm{EB}=$ essentially barren, $\mathrm{B}=$ barren, $\mathrm{G}=\mathrm{g}$,
a Evidence from ammonites indicates that this interval is reworked (see text and Young, this volume).

Cruciellipsis cuvillieri. Stratigraphically lower samples with similar preservational conditions contain numerous $C$. cuvillieri despite the relatively high degree of diagenetic alteration. This species, as pointed out by Roth (1978), is one of the most easily recognizable nannofossil even after significant diagenesis. Thus, the absence of $C$. cuvillieri in samples from Core 535-47 is interpreted as being of biostratigraphic, rather than preservational, significance.

Nannofossil preservation is generally better in the underlying strata. The olive black, marly limestones become more frequent and contain significantly less detri- 
Table 1. (Continued).

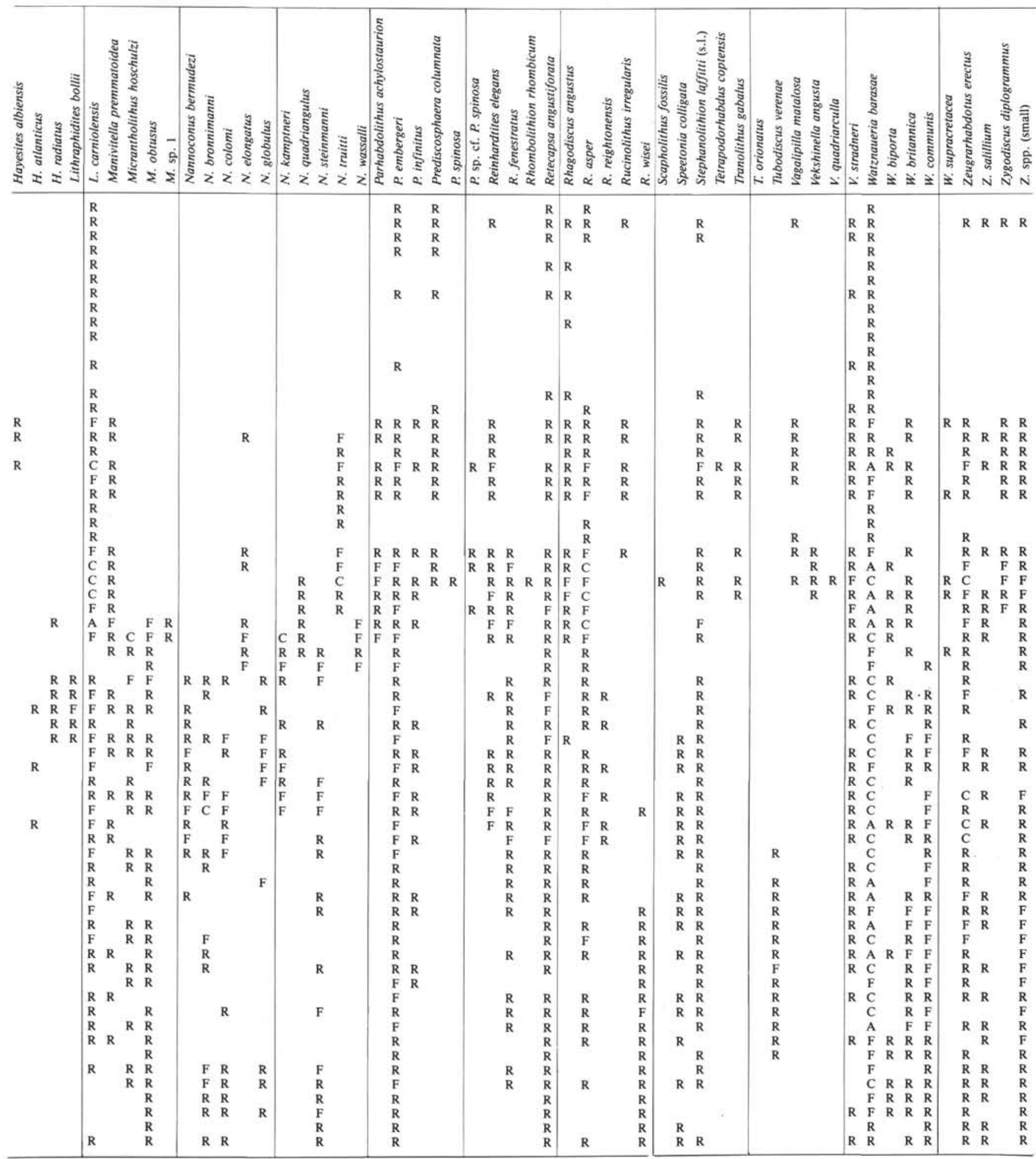

tal carbonate material. Many of these limestones feature fine-scale laminations, relatively high organic contents, and the "speckled" appearance characteristic of numerous coccolith-bearing fecal pellets (Hattin, 1975). Preservation is often quite good, with coccospheres (predominantly of Watznaueria barnasae) composing up to $3 \%$ of the sediment as determined from smear-slide anal- ysis. Nannofossil biostratigraphy reveals a relatively complete, but not necessarily continuous, late Berriasian through late Hauterivian section extending from Cores 535-48 through 535-79 (TD).

The marker species Lithraphidites bollii occurs in samples from the interval of Sample 535-47,CC through Section 535-52-1, indicating the $L$. bollii Zone (late 
Hauterivian to early Barremian). Other workers (e.g., Wind and Cepek, 1979) have noted that the biostratigraphic range of this species may be affected by preservational conditions. At Site 535, this species is identifiable throughout this interval in all but the worst preservational conditions. In addition, it does not occur in well-preserved samples outside of this interval. Although this species is useful for the tropical assemblages at Site 535 , its biostratigraphic utility is limited by paleobiogeographic constraints. Thierstein (1976) indicated that the first occurrence of $L$. bollii is of use only in tropical assemblages. Roth (1978) used the first occurrence of this species as an indicator for his subzone NC4b. The use of the first $L$. bollii as a (tropical) subzone indicator (Roth, 1978) is probably a better approach than using it as a zonal indicator. The former treatment would allow zonal subdivision when paleobiogeographic and preservational conditions permit without overly restricting the use of the zonation scheme as a whole. This datum has been used as a zonal indicator at Site 535, however, in order to remain consistent with the zonation of Thierstein $(1971,1973)$.

The olive-black, marly limestones in Cores 535-52 through $535-60$ contain relatively rich nannofloras. The occurrence of Calcicalithina oblongata and Cretarhabdus loriei without $L$. bollii indicates the upper (early Hauterivian) portion of the Calcicalithina oblongata Zone. Preservation is typically moderate to good, with excellent preservation in Sample 535-58-4, 110-112 cm. Coccospheres (predominantly of Watznaueria barnasae) are common to frequent in concentrated nannofossil preparations of samples from these dark, marly limestones. Dolomite rhombs, framboidal pyrite, and abundant organic material are common constituents of smear slides, indicating reducing conditions in the sediment.

The interval from Core 535-61 through Section 53572-2 contains some moderately rich, moderately well preserved nannofossil assemblages containing $C$. oblongata, Tubodiscus verenae, and Rucinolithus wisei but lacking Cretarhabdus loriei. The presence of Calcicalithina oblongata without Cretarhabdus loriei indicates the Valanginian portion of the Calcicalithina oblongata Zone. This age assignment is in basic agreement with information provided by palynomorphs (Riley and Fenton, this volume) and, from Core 65 downward, by calpionellids (Premoli Silva and McNulty, this volume). Roth (1978) used the total range of Tubodiscus verenae and Diadorhombus rectus to define his zone NC3. Wind and Cepek (1979) have pointed out some of the problems with using these two species for biostratigraphic purposes. Diadorhombus rectus is a delicate species that is rather susceptible to dissolution. At Site $535, D$. rectus occurs rarely but consistently from Sections 535-63-4 through 535-68-2, but is absent in samples of similar preservational character from above and below this interval. The consistent occurrence of this species within this restricted interval prompts correlation of this interval with the middle portion of the Valanginian as suggested by Thierstein (1976), Roth (1978), and Perch-Nielsen (1979). The occurrence of $T$. verenae in the interval from Sections 535-59-3 through 535-73-2 is consistent with this age assignment, although the biostratigraphic utility of T. verenae is unclear (Wind and Cepek, 1979). Several omission surfaces (hardgrounds) occur in the interval from Section 535-68-2 through Core 535-79, indicating that this interval is, at least to some degree, a condensed section.

Samples from Section 535-73-2 through Core 535-79 (terminal depth) contain assemblages of the Retecapsa angustiforata Zone (late Berriasian to early Valanginian). The first occurrence of Reinhardtites fenestratus in Sample $535-75-1,143-144 \mathrm{~cm}$ is used to approximate the Berriasian/Valanginian boundary. This approximation seems fairly accurate at Site 535, as calpionellids place this boundary between samples in Section 53576-2 and Core 535-77 (Premoli Silva and McNulty, this volume).

\section{Site $536\left(23^{\circ} 29.39^{\prime} \mathrm{N}, 8^{\circ} 12.58^{\prime} \mathrm{W}\right)$}

Site 536 is located in an area of the southeastern Gulf of Mexico that is underlain by a series of tilted fault blocks. This site was drilled to investigate the nature of the older sediments and basement rock lying beneath the thin cover of Tertiary and Cretaceous pelagic sediments. The majority of this pelagic cover is Tertiary, with only less than $2 \mathrm{~m}$ being of Cretaceous age. This latter inter$\mathrm{val}$, from Samples 536-9-5, $70 \mathrm{~cm}$ through 536-9,CC, is largely composed of graded, laminated, and cross-laminated limestones that consist primarily of foraminifers and clay. This sequence becomes more fine grained upward, with nannofossil-foraminiferal chalks at the top of the interval. This sequence has been interpreted as a hyaloclastite (site chapter 536, this volume). Samples from this interval contain nannofossils from at least three different assemblages. The presence of rare Micula prinsii in some samples from this interval indicates the latest part of the Maestrichtian (Perch-Nielsen, 1979). The majority of samples (including some that contain $M$. prinsii) in this interval, however, contain reworked older forms. Bronsonia parca s.l. is a frequent component of these assemblages, indicating some contribution from reworked Campanian sediments. In addition, very rare, somewhat overgrown, specimens of Nannoconus similar to Nannoconus kamptneri were observed. The presence of these forms indicates that the reworking of significantly older (? Early Cretaceous) sediments contributed a minor part to the sediment in this interval. Because the earliest Paleocene Globigerina eugubina foraminiferal Zone immediately overlies this interval containing the latest Maestrichtian M. prinsii, it appears that the Cretaceous/Tertiary boundary is represented at Sample $536-9-5,70 \mathrm{~cm}$. A burrowed zone at this level, however, indicates that sedimentation did not occur continuously across the boundary. In addition, the nature of the latest(?) Maestrichtian portion of this core (i.e., a hyaloclastite) makes this a poor section for detailed study of the Cretaceous/Tertiary boundary.

The underlying interval from Core 536-10 through Sample 536-21-1, $34 \mathrm{~cm}$ consists of skeletal limestones that are basically barren of nannofossils. One sample, taken from limestone infilling a rudistid fragment in Sample $536-12-1,0-1 \mathrm{~cm}$, contains very sparse and poorly 
preserved nannofossils. Because of the preservational condition of this sample, only a few taxa could be identified. The presence of Prediscosphaera sp. indet. indicates an Albian through Maestrichtian age. Foraminiferal evidence yields a latest Albian (Planomalina buxtorfi Zone) age for this interval (Site Chapter 536, this volume; Premoli Silva and McNulty, this volume).

\section{Site $537\left(2^{\circ} 56.10^{\prime} \mathrm{N}, 8^{\circ} 27.62^{\prime} \mathrm{W}\right)$}

Site 537 was drilled atop a small knoll located about $25 \mathrm{~km}$ north of the Campeche Escarpment near the mouth of Catoche Tongue. The knoll, which stands approximately $300 \mathrm{~m}$ above the Gulf floor, is interpreted to be the uplifted end of one of several basement fault blocks that are seismically evident in this area (site chapter, Site 537 , this volume). This knoll was chosen for drilling because the relatively thin sedimentary cover allows easy access to the underlying basement rocks.

At Site 537, the Cretaceous sediments containing nannofossils consist of a single, 20 -cm bed of white chalk in Sample 537-3-2, 51-71 cm (Table 2). This chalk is bounded on the top by a $10-\mathrm{cm}$ interval (Sample 537$3-2,41-51 \mathrm{~cm}$ ) of hard, yellowish brown limestone fragments interpreted to be a hardground. Nannofossil assemblages in the white chalk contain Chiastozygus litterarius but not Eprolithus floralis or Rhagodiscus angustus, indicating the C. litterarius Zone of early Aptian age. Samples examined from this interval are dominated by a rich assemblage of nannoconids (at least six species) and micrantholiths. Preservation of other nannofossils is poor due to extreme etching, implying that the enrichment in nannoconids and micrantholiths is, at least in part, a dissolution phenomenon. Thierstein (1976) has noted that Nannoconus spp. and Micrantholithus obtusus are more abundant in epicontinental seas and large shelf areas, their abundance decreasing with increasing distance from shelf areas. Thus, the high dominance by the nannoconids and micrantholiths also could be interpreted as a reflection of marginal marine conditions at Site 537 during the early Aptian. Such conditions would be expected considering the relatively short distance to the Campeche Escarpment.

The underlying skeletal limestones (Core 537-4 through Section 537-10-1) and dolomites and clastic sediments (Section 537-10-1 through Core 537-11) are barren of nannofossils.

\section{Site 538 (Hole 538A) $\left(23^{\circ} 50.95^{\prime} \mathrm{N}, 8^{\circ} 9.93^{\prime} \mathrm{W}\right)$}

Hole 538A was drilled on top of Catoche Knoll, a prominent topographic feature located approximately $25 \mathrm{~km}$ northeast of the Campeche Escarpment. Catoche $\mathrm{Knoll}$ is a roughly triangular feature that stands approximately $750 \mathrm{~m}$ above the surrounding Gulf floor. The site was primarily drilled to investigate the nature of the basement rocks underlying the thin sedimentary sequence atop the knoll. The Cretaceous sediments recovered can be broadly divided into two sedimentary sequences: an upper sequence of thin beds of nannofossilforaminiferal chalk and marly limestone separated by unconformities (Samples 538A-21-1, $60 \mathrm{~cm}$ through 538A$23-1,40 \mathrm{~cm}$ ); and a lower sequence of skeletal lime- stones with abundant shallow-water carbonate debris (Samples 538A-23-1, $41 \mathrm{~cm}$ through 538A-30-1, $6 \mathrm{~cm}$ ). Nannofossils are largely limited to the upper sequence.

A prominent, beautifully burrowed, manganese-rich crust separates the overlying Cenozoic from the underlying Cretaceous sediments at Sample 538A-21-1, 57$60 \mathrm{~cm}$. The interval from Samples 538A-21-1, $60 \mathrm{~cm}$ through 538A-21-4, $110 \mathrm{~cm}$ contains the longest sequence of post-Cenomanian, Cretaceous strata recovered to date from this portion of the deep Gulf of Mexico. The sediments in this interval consist of nannofossil-foraminiferal chalks with at least two readily detectable omission surfaces. At least one other hiatus can be detected by paleontological means. The nannofossil biostratigraphy for this interval still is not fully understood. The biostratigraphy presented here is tentative, therefore, with the placement of zonal boundaries being largely dependent on sample distribution. Currently, more detailed sampling is underway, which should shed more light on this interval that is a unique piece of the record of the history of the Gulf. The distribution of species in this interval is illustrated in Table 3.

The uppermost sample (Sample 538A-21-1, 95-97 cm) examined from this interval contains an early Maestrichtian nannofossil assemblage that includes Reinhardtites levis and Prediscosphaera grandis, but lacks Tranolithus orionatus s.l., Broinsonia parca s.l., Quadrum trifi$d u m$, and $Q$. gothicum. This assemblage indicates the $R$. levis Zone. The next, stratigraphically lower Sample 538A-21-2, 41-43 cm contains a slightly older assemblage that includes $B$. parca s.l., T. orionatus, $Q$. trifidum, and $Q$. gothicum, but lacks Eiffelithus eximius and $R$. anthophorus. This assemblage is clearly assignable to the $T$. phacelous Zone. The presence of numerous $B$. parca s.l. in this assemblage indicates the lower portion of this zone (= Zone 23a of Sissingh, 1977), which is of latest Campanian age (see Perch-Nielsen, 1979). This assemblage continues stratigraphically downward to Sample 538A-21-3, $127 \mathrm{~cm}$. Additional sampling and study of this section will reveal whether the apparent absence of the upper portion of the $T$. phacelous Zone is a real phenomenon or merely an artifact of sample spacing.

The interval from Samples 538A-21-3, $128 \mathrm{~cm}$ through $538 \mathrm{~A}-21-4,77 \mathrm{~cm}$ is assigned to the Ceratolithoides aculeus Zone of late Campanian age. The upper portion of this stratigraphic interval contains abundant, well preserved nannofloras in a white chalk. Nannofossils from the lower portion (Sample 538A-21-4, 10-77 cm) of this interval is, in large part, reworked from the underlying Santonian sediments. Some samples, such as Sample 538A-21-4, 51-53 cm, have entirely reworked assemblages (Table 3). Other samples within this interval are dominated by reworked Santonian nannofloras, but contain a few specimens of $C$. aculeus and $B$. parca that indicate the true age (Campanian) of this interval. In addition to reworked nannofloras, foraminiferal preparations recovered reworked Santonian planktonic foraminifers as well as Early Cretaceous (?Valanginian) shallow-water skeletal debris (site chapter, Site 538, this volume; Premoli Silva and McNulty, this volume). 
Table 2. Distribution of Aptian-Albian nannofossils, Holes 538A and 537.

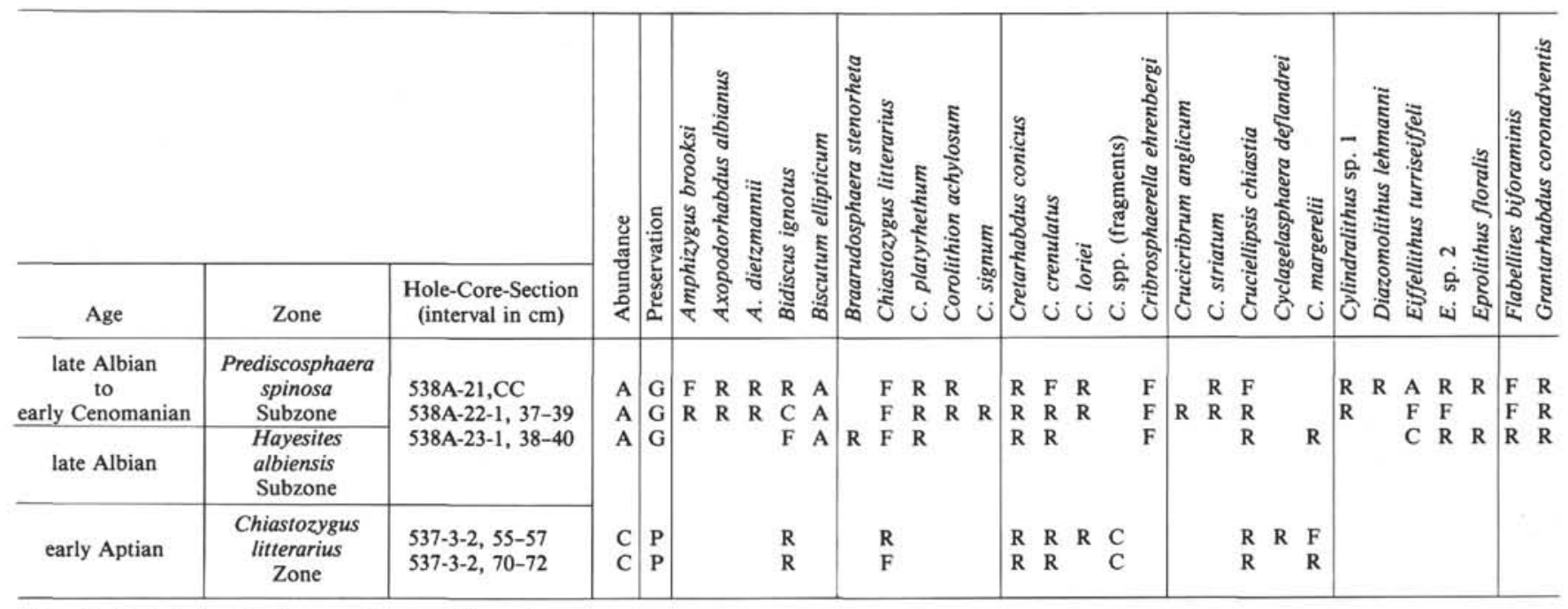

Note: See Table 1 for abundance and preservation codes.

Table 3. Distribution of Late Cretaceous nannofossils, Hole 538A.

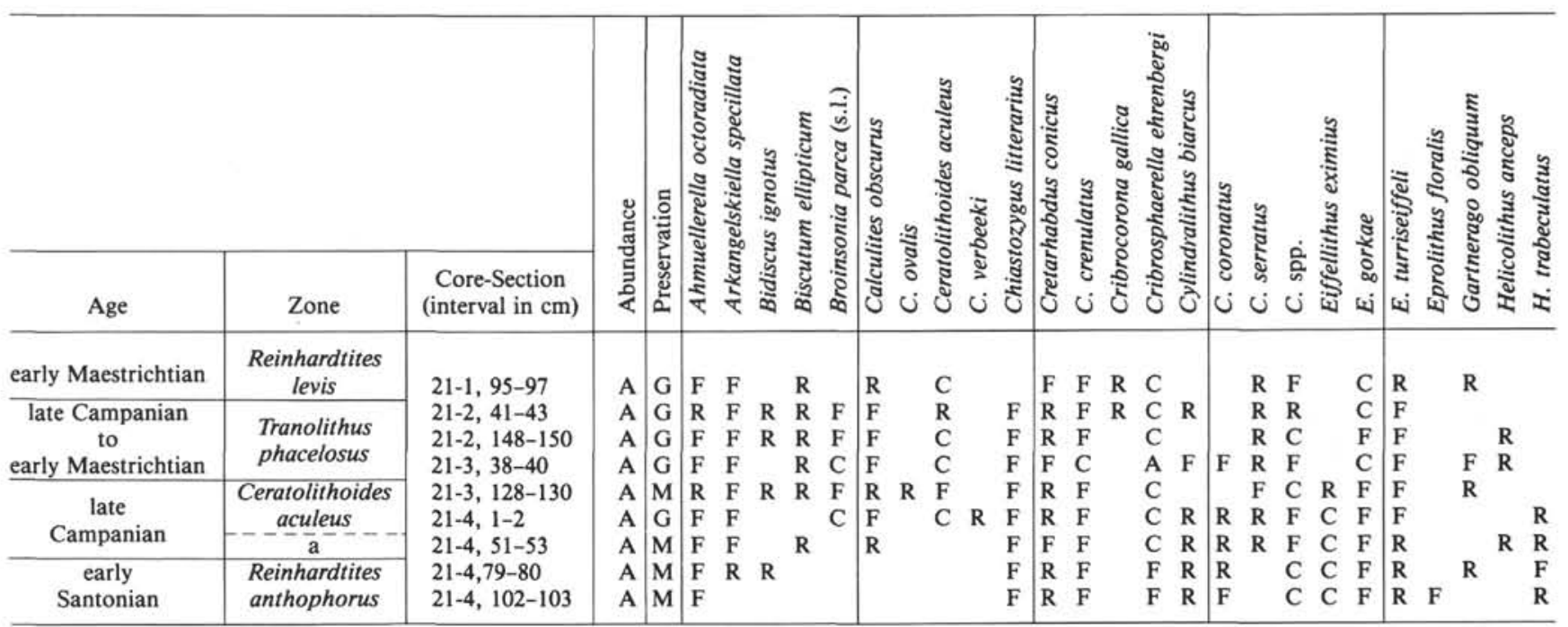

Note: See Table 1 for abundance and preservation codes.

a Reworked from underlying strata, see text.

The interval from Samples 538A-21-4, $78 \mathrm{~cm}$ through $538 \mathrm{~A}-21-4,110 \mathrm{~cm}$ contains nannofossil assemblages of the Reinhardtites anthophorus Zone (early Santonian). Nannofossils are abundant, but only moderately well preserved in this interval. The base of this interval is composed of a brecciated mixture of dark claystone and chalk that lies directly on a high-angle fault. Detailed shipboard study (nannofossils and foraminifers) has indicated that the stratigraphic displacement across this fault is minimal. It may be an artifact of the drilling process.

The underlying interval (Sample 538A-21-4, $110 \mathrm{~cm}$ through Core 538A-23) contains a sequence of lithologies that includes yellow to green claystones, chalks, limestones, and chert. The claystones (largely restricted to the upper portion of this interval) contain very sparse nannofossil assemblages of the $E$. turriseiffeli Zone (late
Albian to early Cenomanian) (Table 2). Better nannofossil preservation in the chalks and limestones downsection allow the division of this interval into two subzones: the Prediscosphaera spinosa Subzone in Sample 538A-21-4, $111 \mathrm{~cm}$ through Core 538A-22 (late Albian to early Cenomanian) and the Hayesites albiensis Subzone in Core 538A-23 (late Albian). Foraminiferal evidence indicates that this entire interval is latest Albian (Planomalina buxtorfi Zone; Premoli Silva and McNulty, this volume).

The underlying oolitic and skeletal limestones in the interval from Core 538A-24 through Sample 538A-30-1, $6 \mathrm{~cm}$ are barren of nannofossils. At the base of this unit (Sample 538A-30-1, 6-7 cm), however, a thin (less than 5 $\mathrm{mm}$ ) film of nannofossil limestone is cemented to the underlying early Paleozoic metamorphic rocks. Although the preserved nannoflora is somewhat sparse 
Table 2. (Continued).

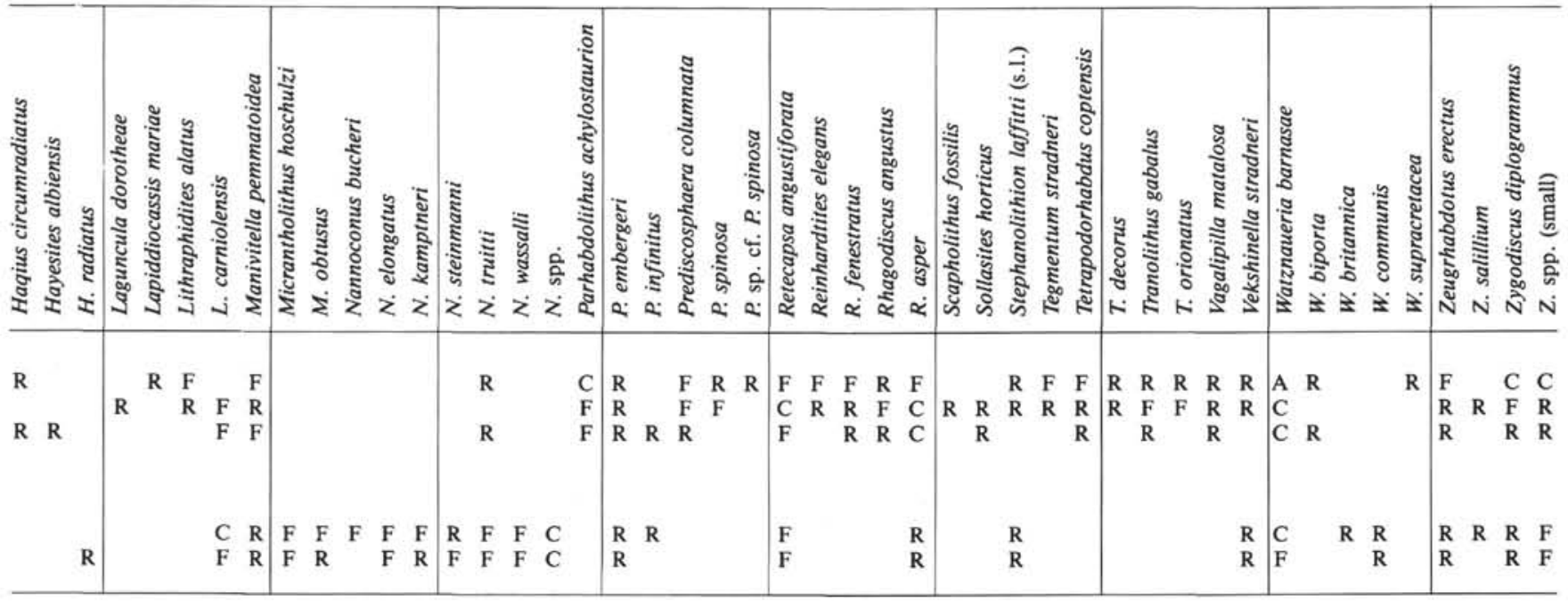

Table 3. (Continued).

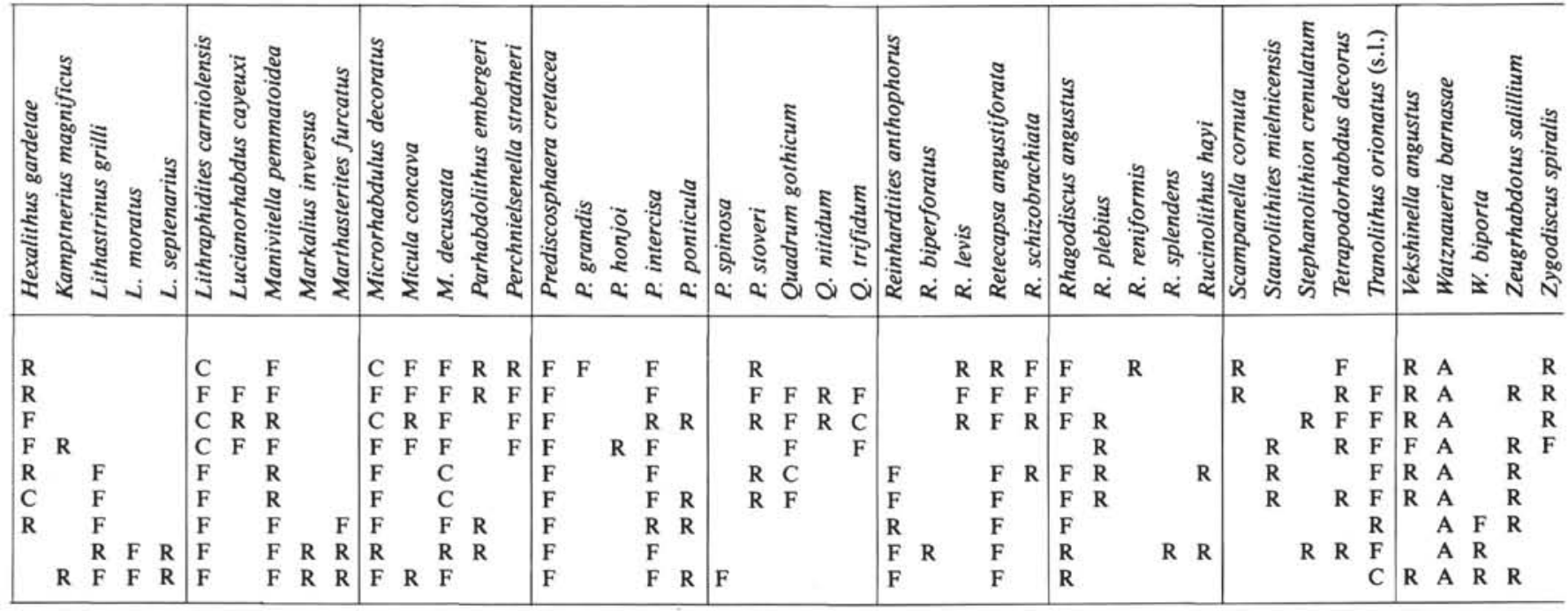

and poorly preserved, several species have been identified. These include Cruciellipsis cuvillieri, $R$. fenestratus, Rhagodiscus asper, Retecapsa angustiforata, Nannoconus colomi, Nannoconus steinmannii, and Nannoconus globulus. Calcicalithina oblongata and Rucinolithus wisei have also been tentatively identified from this assemblage; however, the state of preservation makes the identification of these taxa difficult. The species recovered from this limestone film indicate the Retecapsa angustiforata Zone. The presence of Rhagodiscus asper and Reinhardtites fenestratus in this assemblage probably indicates a Valanginian age, although Perch-Nielsen (1979, fig. 6) has recently extended the age of these taxa into the late Berriasian.

\section{Site $540\left(23^{\circ} 49.73^{\prime} \mathrm{N}, 84^{\circ} 22.25^{\prime} \mathrm{W}\right)$}

Site 540 is located on the flank of a prominent erosional channel near the western end of the Straits of Florida. This site is approximately $20 \mathrm{~km}$ northeast of
Site 535 , to which it can be seismically correlated. Site 540 was drilled in order to retrieve a record of Tertiary and Late Cretaceous sedimentation in the deep Gulf of Mexico, to determine the age of the prominent seismic horizon MCU (middle Cretaceous unconformity), and to examine the strata lying between the MCU and the underlying seismic Horizon 1 (site chapter, Site 540, this volume). Site 540 was the second of two "basin" sites (successfully) drilled in this part of the Gulf. It was located to penetrate the Cretaceous strata that is stratigraphically above the Cretaceous interval recovered at Site 535.

The interval from 540-30-2, $37 \mathrm{~cm}$ through 540-36-1, $60 \mathrm{~cm}$ is composed of a complex sequence of cross-bedded and laminated sandstones, chalks, pebbly chalks, and conglomeratic limestones. This interval corresponds to Lithologic Unit III (site chapter, Site 540, this volume). Much of the sediment included within this.unit is, based on lithologic criteria, obviously reworked. The unit 
can be divided into two subunits, both of which can be broadly characterized as fining upward sequences. Although these two subunits seem to be sedimentologically related, micropaleontological evidence suggests that they are temporally separated by a substantial hiatus.

The upper subunit (IIIa, 540-30-2, $37 \mathrm{~cm}$ through $540-32-1,20 \mathrm{~cm}$ ) contains a variety of nannofossils of different ages in the Maestrichtian and Paleocene. The presence of late Maestrichtian species such as Arkhangelskiella cymbiformis, Lithraphidites quadratus, and Micula mura with such early Maestrichtian (and older) forms such as Tranolithus orionatus and Broinsonia parca indicates that more than one horizon was being cannibalized to form this reworked sediment.

The lower subunit (IIIb; 540-32-1, $21 \mathrm{~cm}$ through 540$36-1,60 \mathrm{~cm}$ ) is composed of similar lithotypes as the overlying Subunit IIIa. The nannoflora preserved in the lower subunit, however, is significantly different from that in the overlying subunit (Table 4). The lower subunit contains some apparently autochthonous chalk beds, one of which (Sample 540-33-1, 67-69 cm) contains a rich, well-preserved nannofossil assemblage. This assemblage contains Crucicribrum anglicum and L. acutum ssp. eccentricum, indicating the L. acutum Zone (early to middle Cenomanian). Samples taken from obviously redeposited material are either barren or contain sparse assemblages that are slightly older (Eiffelithus turriseiffeli Zone; questionably Prediscosphaera spinosa Subzone) than assemblages from the autochthonous chalk beds. The late Albian assemblages in the redeposited material indicate the age of the sediment that is being reworked. Nannofossil evidence suggests, therefore, that the upper subunit is Paleocene whereas the lower subunit is Cenomanian. This suggestion is corroborated by foraminiferal evidence (Premoli Silva and McNulty, this volume).

Below the redeposited interval is a relatively thick, middle Albian through early Cenomanian section (540$36-1,61 \mathrm{~cm}$ through Core 540-79) (Table 4). Rhythmic alternations of light and dark limestones and marly limestones, similar to those observed at Site 535, occur throughout most of this sequence. As at Site 535, the abundance and state of preservation of nannofossil assemblages are strongly controlled by the clay content of the recovered sediment, with relatively higher clay contents covarying with rich, well preserved nannofloras.

Samples from olive gray to olive black, marly limestones in the interval from Cores 540-37 through 540-49 contain rich assemblages of nannofossils from the Eiffelithus turriseiffeli Zone (late Albian to early Cenomanian). Preservation was generally moderately good, although samples from olive black, marly limestones in the basal two cores of this interval (Cores 540-48 and 540-49) contain assemblages that are well preserved and quite diverse (more than 40 species). The extinction of Hayesites albiensis in Section 540-44-2 allows subdivision of this interval into the $H$. albiensis Subzone (late Albian; Cores 540-44 through 540-49) and the P. spino$s a$ Subzone (latest Albian to early Cenomanian; Cores 540-37 through 540-43). Here, as at Site 538, the extinction of $H$. albiensis occurs within the Planomalina buxtorf $f$ f foraminiferal Zone, indicating a latest Albian age.
Ammonites in Sample 540-44-2, 0-8 cm (approximately $65-70 \mathrm{~cm}$ above the sample with the highest occurrence of $H$. albiensis) indicate a late Albian (Stoliczkaia dispar and/or Arrhaphoceras substuderi Zone; Young, this volume). Planktonic foraminifiers place the Albian/Cenomanian boundary between Cores 540-40 and 540-41. No first or last nannofossil occurrences seem to coincide with the boundary thus placed, however nannofossil preservation is poor in this interval.

Cores 540-54 through 540-79 yield assemblages assignable to the Prediscosphaera columnata Zone (early to late Albian). A lithologic change between Cores 54053 and 540-54 (boundary between Lithologic Units IV and V) is marked by the loss of strongly developed cyclicity in the lower unit. The more homogeneous limestones in Cores 540-54 through 540-76 (Lithologic Unit V) exhibit only weakly expressed alternations between light-colored and dark-colored limestones. Because of the generally higher carbonate content of these limestones, nannofossil abundance and preservation are poorer than in the overlying unit. As at Site 535, the expression of cyclicity has been suppressed by the influx of detrital carbonate debris from nearby platform areas. In general, there is an increase in the amount of detrital carbonate in the sediments downcore to Core 540-76. Core 540-77 through 540-79 (Lithologic Unit VI) contain a much larger component of skeletal debris, with skeletal limestones interbedded with finer grained limestones. Nannofossil assemblages from this interval are very sparse ("essentially barren"); however, the presence of $P$. columnata in Cores 540-77 and 540-79 indicate the same zone as in the overlying unit.

\section{SUMMARY AND CONCLUSIONS}

The Mesozoic record recovered on Leg 77 includes sediment that spans almost all of the Cretaceous. Although not all of this Cretaceous record contains nannofossils, they are useful biostratigraphic indicators for much of the sediment recovered. In general, the nannofossil record (and the sedimentological record) is largely restricted to the Berriasian through the Cenomanian, with only minimal amounts of Turonian through Maestrichtian material.

With the exception of one Valanginian(?) sample recovered from Hole 538A, the nannofossil record of the Berriasian through Barremian was recovered only at Site 535 . At this site, a relatively thick $(286 \mathrm{~m})$ section of carbonates of this age was recovered. Biogenic carbonate debris derived from nearby carbonate platforms is evident, to a varying degree, throughout this section. This material, when prevalent, raised sediment carbonate content above a level at which nannofossils were destroyed by secondary alteration. This diagenetic alteration may have been facilitated, at least in part, by the introduction of aragonitic, biogenic debris from the platforms. Rhythmic decrease in the influx of platform-derived carbonate, increased clay content, and sediment anoxia resulted in the periodic deposition of marly limestones with relatively well preserved nannofossil assemblages throughout this interval. These assemblages show close affinities to other coeval tropical assemblages (e.g., Wor- 
sely, 1971; Thierstein, 1971, 1973; Roth, 1978; Wind and Cepek, 1979). Tropical marker species such as Lithraphidites bollii and Diadorhombus rectus are common enough to be useful for biostratigraphic subdivision. Some marker species documented from boreal regions, such as Chiastozygus striatus and (to a lesser extent) Speetonia colligata, were only sporadically observed and, thus, of only limited biostratigraphic utility.

Nannofossil biostratigraphy for this interval indicates a relatively complete (but not necessarily continuous) record of sedimentation from the late Berriasian through the late Hauterivian. The latest Hauterivian and the Barremian are either missing or very thin and not recovered during the drilling at Site 535. The latter situation may be the case as core recovery was poor at this point. In addition, the overlying few cores indicate a condensed section including the Aptian and much of the Albian.

The Aptian is recorded in thin beds of pelagic sediment recovered at Sites 535 and 537. The thin nature of the Aptian is understandable at Site 537. This site is atop a knoll, which would have been exposed to the erosive force of any current activity during the Aptian. The thin Aptian section at Site 535, however, indicates a great decrease in sedimentation rate in the deep basin of the southeastern Gulf of Mexico. This decrease is probably due in large part to a halt in the influx of detrital carbonate into the basin.

The Albian and Cenomanian (especially the late Albian) are better represented in the recovered sedimentary record. At Site 535, a thick (245 m) section of Albian and Cenomanian rocks contain very sparse, largely reworked nannofossil assemblages with a large component of carbonate debris shed from nearby platforms. At Site 540, the Albian and Cenomanian are also thick, although nannofossils are better preserved and apparently not reworked. The Albian sediments are similarly dominated by carbonate debris. The latest Albian and much of the Cenomanian show a return to periodic bottom anoxia with a concomitant improvement in the nannofossil record. An even better nannofossil record of the latest Albian was recovered from Site 538 .

At some point during the middle to late Cenomanian a profound erosional event (or series of events) occurred in the southeastern Gulf of Mexico. Large-scale reworking of sediment within the basin resulted in the deposition of graded pebbly mudstones. These were recovered at Site 540 as well as at nearby Sites 95 and 97 (Worzel, Bryant, et al., 1973). The clasts in these pebbly mudstones were largely derived from late Albian and/or early Cenomanian limestones. Much of the matrix of these black pebbly mudstones was probably derived from the pyrite-rich, black marly limestones and/or shales of similar age.

The basic nature of the sedimentation in this region of the Gulf changed following the Cenomanian erosional event(s). The history of the rest of the Cretaceous (as well as most of the Cenozoic) is largely represented only by unconformities. Aside from obviously redeposited material, only about $5 \mathrm{~m}$ of sediment (aside from thin, obviously redeposited beds) was recovered from the entire Turonian through Maestrichtian of this portion of the gulf. This record, at Site 538, was recovered from atop a prominent topographic high (Catoche Knoll). The thin, condensed nature of this post-Turonian record at Site 538 is understandable considering the exposed nature of the top of the knoll. However, no post-Cenomanian Cretaceous sediment (aside from thin, obviously redeposited beds) was recovered from the basin sites at all. The absence of sediment of this age from the deep basin sites may not be representative of the situation in the rest of the southeastern Gulf of Mexico. Both of the basin sites were located on an erosional slope at the western end of the Straits of Florida. Strong currents flowing through the Straits may have eroded post-Cenomanian sediments subsequent to their deposition. Drilling at Site 95 , located some $400 \mathrm{~km}$ west of the study area and away from the direct influence of the Straits of Florida, penetrated a 43-m-thick sequence of Santonian and lower Campanian calcareous pelagic sediment $\mathrm{Bu}-$ kry, 1973; Hay, 1973). Additional study of the post-Cenomanian sediment recovered on Leg 77 as well as a restudy of the Site 95 material (currently in progress) should clarify our knowledge of conditions in the Late Cretaceous southeastern Gulf of Mexico.

\section{SYSTEMATIC PALEONTOLOGY}

\section{Genus CYLINDRALITHUS Bramlette and Martini, 1964}

\section{Cylindralithus sp. 1}

Description. This form of Cylindralithus has a proximal shield consisting of two cycles of imbricated elements. The outer cycle is formed by $25-30$ obliquely imbricated elements that give the proximal rim a ragged or blocky outline. The inner cycle of elements consists of 22-27 dextrally imbricated elements, forming a smooth central area outline. The central area is devoid of any bridging structure. The distal shield consists of a single cycle of 22-27 elements that (in distal view) are dextrally imbricated. These elements form a steep-sided cylinder that flares very little in the distal direction.

Remarks. This form occurs sporadically in the upper Albian through middle Cenomanian at sites 538 and 540 .

\section{Genus DARWINILITHUS Watkins n. gen.}

Type species. Darwinilithus pentarhethum Watkins, n. sp.

Diagnosis. A calcareous nannofossil composed of a flaring, bowllike distal shield, a more or less horizontal, proximally-curving proximal shield, and a number of proximally directed processes that arise from the central area.

Remarks. The possession of two shields of imbricated elements indicates that this genus is a true fossil coccolith, as opposed to a calcareous nannofossil of uncertain biological affinities. The orientation of these nannofossils is not readily discernible at first glance. The curvature of the shields, however, indicates that the flaring, bowl-shaped shield is distal and the horizontal shield is proximal. Given this orientation, the processes must be radiating outward from the central area in the proximal direction. The possession of structures that flare outward in both the proximal and distal directions is relatively unusual for a fossil coccolith.

The general form of a flaring, bowl-like shield and a more or less flattened, horizontal shield seen in Darwinilithus is similar to that seen in some forms of Cylindralithus Bramlette and Martini (1964). The major difference between these two genera is the possession of proximally directed processes in Darwinilithus. These processes have no counterpart in Cylindralithus. Possibly, the processes of Darwinilithus are preservational artifacts resulting from secondary overgrowth of elements in the central area of the proximal shield. Examination of more than 50 specimens of this taxon, however, indicate that the size, shape, number, and placement of these processes is typical of these forms. On the basis of these observations, we believe that the processes are original features of the taxon. Assignment of this form to the genus Cylindralithus would not, therefore, be consistent with the definition of this genus. Thus, the new genus Darwinilithus has been pro- 
Table 4. Distribution of Albian-Cenomanian nannofossils, Hole 540.

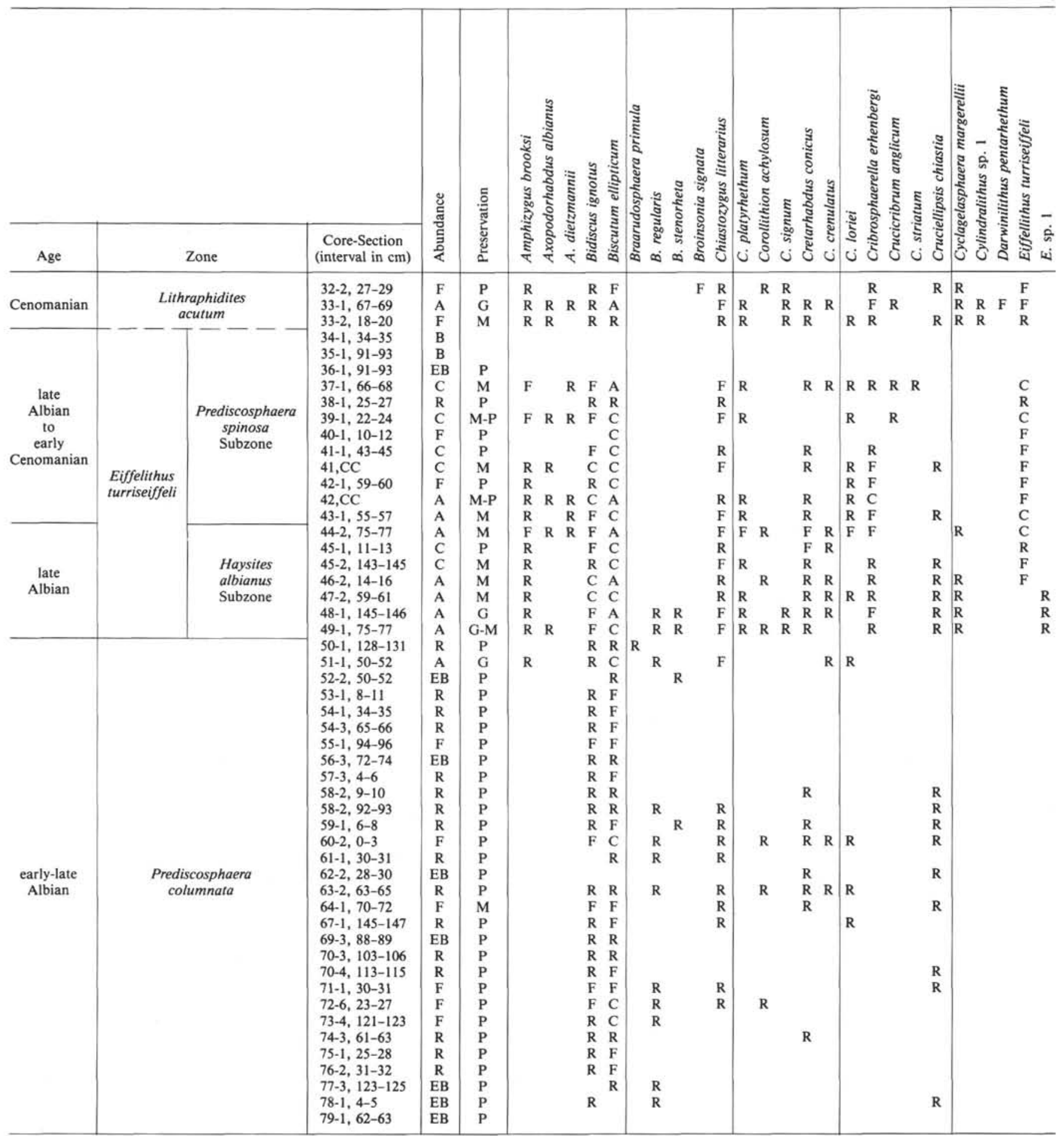

Note: See Table 1 for abundance and preservation codes.

posed to include these process-bearing forms. Despite this assignment, however, the morphologic similarities of Darwinilithus and Cylindralithus imply a relatively close taxonomic relationship between these two genera.

Darwinilithus pentarhethum Watkins, $\mathbf{n}$. sp.

(Plate 1, Figs. 1-6; Plate 2, Figs. 1-6; Plate 3, Figs. 1-8)

Description. The proximal shield of this coccolith is composed of 35-40 lathlike elements that are dextrally imbricated. This shield may be flat, or the periphery of the shield may curve slightly in the proximal direction. The distal shield is composed of a single cycle of 24-28 lathlike elements that (in distal view) are dextrally imbricated. These elements form an angle of $60-70^{\circ}$ with the plane of the proximal shield, resulting in a conical distal shield that flares outward. Five robust, rodlike processes arise from the proximal side of the central area. These processes flare outward in the proximal direction, forming an angle of $60-75^{\circ}$ with the plane of the proximal shield.

Remarks. This form seems relatively susceptible to dissolution. With the exception of the proximal processes, all of the structural elements 
Table 4. (Continued).

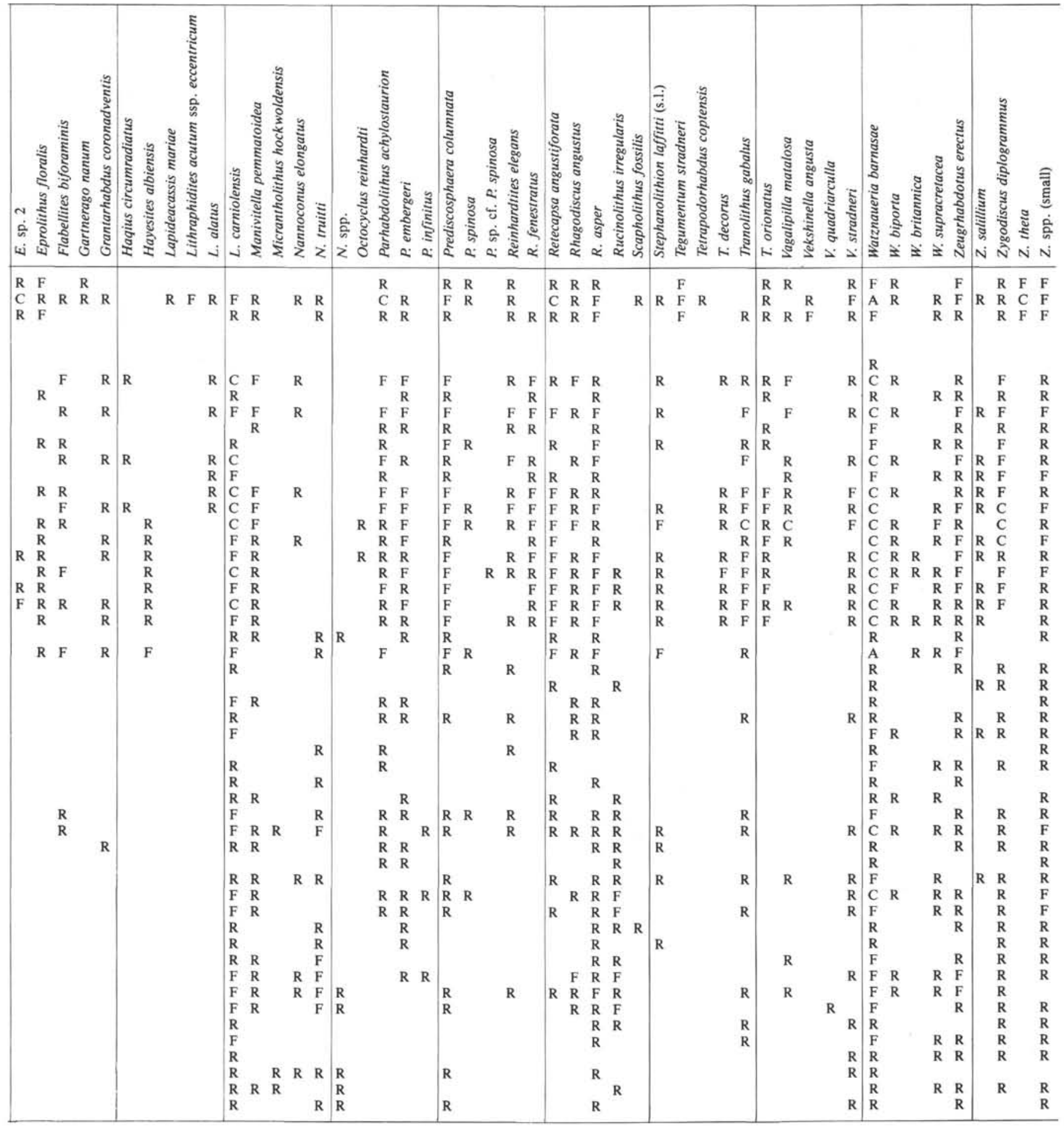

exhibit some etching even when other nannofossils in the assemblage show little secondary alteration. This gives the edges of the distal and proximal shields a distinctly ragged appearance. The processes, on the other hand, generally exhibit some degree of overgrowth. The robust nature of the processes on the specimens examined in this study is, at least in part, the result of overgrowth of somewhat thinner process elements. The blunt tips of the processes of many specimens are also the result of secondary alteration.
Secondary alteration has a marked effect on the preserved dimensions of several features in this species, especially the diameter of the proximal and distal shields. The following measurements were taken from well-preserved specimens. Poorer preservation would yield specimens with smaller proximal and distal rims and, perhaps, larger processes. The proximal shield has a width of 5-8 $\mu \mathrm{m}$. The distal shield has a height of $2.5-3 \mu \mathrm{m}$ above the plane of the proximal shield. The processes are typically $2.5-3 \mu \mathrm{m}$ in length. 
Holotype. Plate 1, Figs. 1-3.

Paratypes. Plate 1, Figs. 1-3; Plate 3, Figs. 3-8. Type locality. DSDP Site 540, Sample 540-33-1, 67-69 cm. Age. Middle Cenomanian.

\section{Genus EIFFELITHUS Reinhardt, 1965 Eiffelithus sp. 1}

Description. This form of Eiffelithus is an elliptical coccolith with a thin, imbricated distal rim. The relatively large central area contains a prominent stem, the base of which forms a cross. The axes of this cross form an angle of $10-15^{\circ}$ with the major and minor axes of the coccolith. The remainder of the central area is filled with numerous (more than 10) elements that radiate inward from the distal rim.

Remarks. This form is morphologically similar to Eiffelithus eximius in the orientation of the cross arms of the stem base. This form, however, has a distinctly thinner distal rim than $E$. eximius. In addition, the number of elements in the inner cycle is significantly greater in Eiffelithus sp. 1 than in E. eximius. Finally, E. sp. 1 occurs only during a short interval in the late Albian. This form seems to be the same as Eiffelithus sp. 1 of Perch-Nielsen (1979).

Occurrence. Site 540, Cores 47-49 (late Albian).

\section{Eiffelithus sp. 2}

Description. This form of Eiffelithus is an elliptical coccolith with a stem base cross whose axes form an angle of $30-40^{\circ}$ with the axes of the coccolith. The four arms of the stem base cross are composed of two optically distinct sets of crystallites. The tips of the cross arms are distinctly bifid in well-preserved specimens.

Remarks. This form seems to be the same as Eiffelithus sp. 2 of Perch-Nielsen (1979).

Occurrence. Hole 538A, Cores 21-23; Site 540, Cores 32-48 (upper Albian to middle Cenomanian).

\section{Genus LITHRAPHIDITES Deflandre, 1963}

Lithraphidites acutum ssp. eccentricum Watkins, n. ssp. (Plate 4, Figs. 1-6; Plate 5, Figs. 1-4)

Diagnosis. A form of Lithraphidites with four bilamellar blades that expand to form four prominent, triangular processes near one of the poles of the central shaft of the nannofossil.

Description. The central shaft of this rodlike nannofossil is formed by the intersection of four bilamellar blades, each of which gives rise to a prominent triangular process, where the major axis is perpendicular to the major axis of the central shaft. These processes arise twothirds to three-fourths of the distance along the major axis of the central shaft. The processes effectively divide the central shaft into two markedly unequal portions. In well-preserved specimens, both shaft poles taper to a fine point.

Remarks. Lithraphidites acutum ssp. acutum Verbeek and Manivit in Manivit et al., 1977, has four triangular processes arising from a point at or near the center of the central shaft. The processes divide the central shaft of that taxon into two equal or subequal portions. The new subspecies differs by virtue of the markedly asymmetrical placement of the processes on the central shaft.

At Site $540, L$. acutum ssp. eccentricum occurs frequently in the autochthonous chalk beds in the interval from Section 540-32-1 through $540-33$, CC. It is not present in the obviously reworked portions of this interval. Lithraphidites acutum ssp. acutum has not been observed in any samples from this interval. Planktonic foraminiferal evidence (as well as less definitive nannofossil evidence) indicates a middle Cenomanian age (Rotalipora cushmani Zone, Rotalipora appenninica Subzone, Premoli Silva and McNulty, this volume) for this interval. The absence of $L$. acutum ssp. acutum does not, therefore, appear to be due to biostratigraphic contraints. More likely, L. acutum ssp. acutum and $L$. acutum ssp. eccentricum are paleobiogeographic variations (form subspecies) of the same species.

The length of the central shaft of specimens of L. acutum ssp. eccentricum varies significantly. Well-preserved specimens, in which both poles of the central shaft taper to a fine point, range in length from 14 to $27 \mu \mathrm{m}$. Some of this variation is, no doubt, due to secondary dissolution of the fine shaft tips. The specimens in the best-preserved material (from Section 540-33-1) are typically $15-19 \mu \mathrm{m}$ in central shaft length. The processes are typically $4-5 \mu \mathrm{m}$ in height (measured per- pendicularly from the base of the process to the tip). The shape and, to a lesser extent, the size of the processes are strongly effected by secondary alteration. Even in samples where secondary alteration was relatively intense, however, this new subspecies is easily distinguishable from morphologically similar and biostratigraphically coeval forms such as Lithraphidites alatus (which L. acutum ssp. eccentricum occurs with in the Site 540 material) and Lithraphidites acutum spp. acutum.

Holotype. Plate 4, Figs. 1-2.

Paratypes. Plate 4, Figs. 3-6; Plate 5, Figs. 1-4.

Type locality. DSDP Site 540, Sample 540-33-1, 67-69.

Age. middle Cenomanian.

\section{Genus MICRANTHOLOTHUS Deflandre, 1950}

\section{Micrantholithus sp. 1}

Description. A small form of Micrantholithus with five, thin arms formed by the deep negative angle in each segment. Each arm has a prominent line down its long axis, corresponding to the juncture of the segments.

Remarks. This form appears to be the same as Micrantholithus sp. 1 of Perch-Nielsen (1979), as its appearance and biostratigraphic range are identical. It is similar to, but smaller than, $M$. aequalis Sullivan, 1964.

Occurrence. Site 535, Core 44 (upper Aptian).

\section{Genus PERCHNIELSENELLA Watkins, n. gen.}

Type species. Perchnielsenella stradneri (Perch-Nielsen) Watkins, n. comb.

Diagnosis. A calcareous nannofossil constructed of a single cycle of more than 20 elements that are, at least in part, strongly imbricated and form a hollow, robust cylinder. A horizontal platform composed of numerous elements spans the central portion of the interior of the cylinder.

Remarks. This genus seems to be most closely allied to the Eprolithus-Lithastrinus group of calcareous nannofossils. Both Eprolithus and Perchnielsenella have a well-developed central cylinder formed by a single cycle of robust and generally vertical elements. This central cylinder is spanned by a more or less horizontal platform made of radially arranged crystallites. These same features, albeit less well expressed, are present in Lithastrinus as well. Perchnielsenella differs from both Eprolithus and Lithastrinus in the strongly imbricated nature of the elements that make up the cylinder wall and by the generally larger number of these elements in Perchnielsenella.

Another taxon, Cylindralithus? oweinae Perch-Nielsen, 1973, may belong to Perchnielsenella. The proximal view illustrated by PerchNielsen (1973, plate 5, fig. 1) shows a form with a central platform which is essentially identical to that found in P. stradneri. The holotype of C.? oweinae (Perch-Nielsen, 1973, plate 4, fig. 8) illustrates the imbricated nature of the elements making up the main wall of this form. It is difficult to ascertain with certainty (from these micrographs) whether C.? oweinae is composed of one or two cycles of elements. A prominent indentation at about the height of the platform (seen in PerchNielsen, 1973, plate 4 , figs. 7,8 ) may be the line of suture between two cycles of elements or a line delineating a sharp bend in a single cycle of elements which has been enhanced by dissolution. If the latter is true, this taxon belongs in Perchnielsenella. If, however, two distinct cycles of elements are present, this species must be assigned elsewhere. Even if this is the case, this taxon does not seem to conform to the generic definition of Cylindralithus. Because no specimens of this taxon were recovered in the present study and the doubt regarding the exact construction of this nannofossil, no taxonomic reassignment is appropriate at this time. This species, however, is not considered to be a member of the genus Cylindralithus in the discussion of Perchnielsenella stradneri in the following section.

Perchnielsenella stradneri (Perch-Nielsen) Watkins, n. comb.

(Plate 5, Figs. 5, 6; Plate 6, Figs. 1-9; Plate 7, Figs. 1, 2, 4)

Lithastrinus? stradneri Perch-Nielsen, 1973, p. 317 , pl. 5, figs. 7, 8 , pl. 10, figs. 23, 24 .

Cylindralithus stradneri (Perch-Nielsen) Romein, 1977, p. 276, pl. 2, figs. 6a-c.

Remarks. This species has been well described by Perch-Nielsen (1973) and Romein (1977). Perch-Nielsen (1973) questionably placed 
this species in the genus Lithastrinus, presumably based on the general construction of the nannofossil and the nature of the platform that spans the hollow, cylindrical central area. As mentioned previously, this species is probably closely allied to the Eprolithus-Lithastrinus lineage. The strongly imbricated nature of the wall elements in Perchnielsenella stradneri, however, warrants separation from these other two genera.

Romein (1977) transferred this species to the genus Cylindralithus. There are several features, however, that suggest that this species is not allied with this genus. Species of Cylindralithus (including the type species C. serratus Bramlette and Martini, 1964) are composed of two separate shields, each of which is composed of one or more cycles of elements. The distal shield is typically vertical or steeply inclined, forming a vertical cylinder or a flaring, bowl-shaped structure. The proximal shield is typically composed of one or more cycles of radial elements which are either flat-lying (Plate 7, Fig. 6) or proximally flaring (as in C. duplex Perch-Nielsen, 1973). Perchnielsenella stradneri is composed of only one cycle of robust wall elements. Several species of Cylindralithus have structures that span the central area. These structures are typically some form of cross developed at the proximal end of the nannofossil, within the elements of the proximal shield (Plate 7, Fig. 4). In P. stradneri, however, the central structure is a slightly curving platform which occurs within the cylinder, well away from the proximal end (see Plate 5, Figs. 5, 6; Plate 6, Figs. 1, 2). Finally, the strongly imbricated nature of the distal surface of $P$. stradneri is not typical of Cylindralithus.

This species has been reported from the Maestrichtian Lithraphidites quadratus Zone of Madagascar (Perch-Nielsen, 1973, type locality) and the Maestrichtian Micula mura Zone of Spain (Romein, 1977). The latter author also reported this species from the basal Danian of Spain, but these occurrences are probably the result of reworking across the Cretaceous/Tertiary bundary. In the southeastern Gulf of Mexico, P. stradneri has been observed in the Maestrichtian Reinhardtites levis Zone and the latest Campanian Tranolithus phacelosus Zone.

Holotype. Perch-Nielsen, 1973, pl. 5, fig. 7.

\section{Genus RHAGODISCUS Reinhardt, 1967}

Rhagodiscus reightonensis (Taylor) Watkins, $\mathbf{n}$. comb.

Parhabdolithus reightonensis Taylor, 1978, p. 200, pl. 6, figs. 1, 2.

Remarks. As noted by Taylor (1978), this species is morphologically similar to Rhagodiscus asper but has a notably wider distal rim. This species occurs sporadically throughout the Hauterivian of Site 535.

\section{ACKNOWLEDGMENTS}

We would like to thank the Deep Sea Drilling Project and our cochief scientists, Wolfgang Schlager and Richard T. Buffler, for giving us the opportunity to participate in Leg 77. The other shipboard paleontologists, Isabella Premoli Silva and Charles L. McNulty, were ideal shipmates. Our long hours of shared investigation and discussion contributed much of whatever is meritorious in this paper. Mary Anne Holmes assisted the senior author in too many ways to detail; her help is gratefully acknowledged. Brian Caldwell spent many hours assisting the senior author in putting together the manuscript and illustrations. He also assisted William I. Miller III, who expertly tickled the SEM to give us the best possible results under the circumstances. Discussions on taxonomy with Sherwood W. Wise, Jr., George E. Wiegand, and James A. Bergen were very helpful to the senior author. The project benefited from laboratory facilities maintained at Florida State University by National Science Foundation Grants DES 80-25489 and DPP 80-20382. The manuscript was reviewed by Frank H. Wind, Sherwood W. Wise, Jr., and an anonymous reviewer, for which we are grateful.

\section{REFERENCES}

Bramlette, M. N., and Martini, E., 1964. The great change in calcareous nannoplankton fossils between the Maestrichtian and Danian. Micropaleontology, 10:291-322.

Bukry, D., 1973. Coccolith stratigraphy, Leg 10, Deep Sea Drilling Project. In Worzel, J. L., Bryant, W., et al., Init. Repts. DSDP, 10: Washington (U.S. Govt. Printing Office), 385-406.

Hay, W. W., 1970. Calcareous nannofossils from cores recovered on Leg 4. In Bader, R. G., Bryant, R. D., et al., Init. Repts. DSDP, 4: Washington (U.S. Govt. Printing Office), 455-501.
1973. Preliminary dating by fossil calcareous nannoplankton, Deep Sea Drilling Project: Leg 10. In Worzel, J. L., Bryant, W., et al., Init. Repts. DSDP, 10: Washington (U.S. Govt. Printing Office), 375-383.

Loeblich, A. R., Jr., and Tappan, H., 1966. Annotated index and bibliography of the calcareous nannoplankton. Phycologia, 5:81-216. 1968. Annotated index and bibliography of the calcareous nannoplankton II. J. Paleontol., 42:584-598.

, 1969. Annotated index and bibliography of the calcareous nannoplankton III. J. Paleontol., 43:568-588.

1970a. Annotated index and bibliography of the calcareous nannoplankton IV. J. Paleontol., 44:558-574.

$1970 \mathrm{~b}$. Annotated index and bibliography of the calcareous nannoplankton V. Phycologia, 9:157-174.

1971. Annotated index and bibliography of the calcareous nannoplankton VI. Phycologia, 10:315-339.

, 1973. Annotated index and bibliography of the calcareous nannoplankton. J. Paleontol., 47:715-759.

Manivit, H., 1981. Les nannofossiles du Cretácé moyen europeen. Cretaceous Res., 2:361-369.

Manivit, H., Perch-Nielsen, K., Prins, B., and Verbeek, J. W., 1977. Mid-Cretaceous calcareous nannofossil biostratigraphy. Kon. Ned. Akad. Wet. B, 80:169-181.

Perch-Nielsen, K., 1973. Neue Coccolithen aus dem Maestrichtien von Danemark, Madagaskar und Agypten. Geol. Soc. Denmark Bull., 21:51-66.

1979. Calcareous nannofossils from the Cretaceous between the North Sea and the Mediterranean. In Aspecte der Kriede Europas: Stuttgart, IUGS Ser. A, 6:223-272.

Romein, A. J. T., 1977. Calcareous nannofossils from the Cretaceous/ Tertiary boundary interval in the Barranco del Gredero (Caravaca, Prov. Murcia, S. E. Spain) I. Kon. Ned. Akad. Wet. B, 80:256-279.

Roth, P. H., 1973. Calcareous nannofossils-Leg 17, Deep Sea Drilling Project. In Winterer, E. L., Ewing, J. L., et al., Init. Repts. DSDP, 17: Washington (U.S. Govt. Printing Office), 695-795.

1978. Cretaceous nannoplankton biostratigraphy and oceanography of the northwestern Atlantic Ocean. In Benson, W. E., Sheridan, R. E., et al., Init. Repts. DSDP, 44: Washington (U.S. Govt. Printing Office), 731-759.

Sissingh, W., 1977. Biostratigraphy of Cretaceous calcareous nannoplankton. Geol. Mijnbouw, 56:37-65.

Taylor, R. J., 1978. The distribution of calcareous nannofossils in the Speeton Clay (Lower Cretaceous) of Yorkshire. Proc. Yorkshire Geol. Soc., 42:195-209.

1982. Lower Cretaceous (Ryazanian to Albian) calcareous nannofossils. In Lord, A. R. (Ed.), A Stratigraphic Index of Calcareous Nannofossils: Chichester, England (Ellis Horwood Ltd.), pp. $40-80$.

Thierstein, H. R., 1971. Tentative Lower Cretaceous calcareous nannoplankton zonation. Ecologae Geol. Helv., 64:459-488.

,1973. Lower Cretaceous calcareous nannoplankton biostratigraphy. Abh. Geol. Bundesanst, Wien, 29:1-52.

1974. Calcareous nannoplankton-Leg 26, DSDP. In Davies, T. A., Luyendiyk, B. P., et al., Init. Repts. DSDP, 26: Washington (U.S. Govt. Printing Office), 619-668.

1976. Mesozoic calcareous nannoplankton biostratigraphy of marine sediments. Mar. Micropaleontol., 1:325-362.

van Heck, S. W., 1979a. Bibliography and taxa of calcareous nannoplankton. Int. Nannoplankt. Assoc. Newsl., 1:AB1-5, A1-12, B1-27.

1979b. Bibliography and taxa of calcareous nannoplankton. Int. Nannoplankt. Assoc. Newsl., 1:AB-VI, A13-28, B28-42.

1980a. Bibliography and taxa of calcareous nannoplankton. Int. Nannoplankt. Assoc. Newsl., 2:5-34.

1980b. Bibliography and taxa of calcareous nannoplankton. Int. Nannoplankt. Assoc. Newsl., 2:43-81.

, 1981a. Bibliography and taxa of calcareous nannoplankton. Int. Nannoplankt. Assoc. Newsl., 3:4-41.

,1981b. Bibliography and taxa of calcareous nannoplankton. Int. Nannoplankt. Assoc. Newsl., 3:51-86.

1982a. Bibliography and taxa of calcareous nannoplankton. Int. Nannoplankt. Assoc. Newsl., 4:7-50.

,1982b. Bibliography and taxa of calcareous nannoplankton. Int. Nannoplankt. Assoc. Newsl., 4:65-96. 
Wind, F. H., and Čepek, P., 1979. Lower Cretaceous calcareous nannoplankton from DSDP Hole 397A (northwest African margin). In von Rad, U., Ryan, W. B. F., et al., Init. Repts. DSDP, 47: Washington (U.S. Govt. Printing Office), 221-255.

Wise, S. W., and Kelts, K. R., 1972. Inferred diagenetic history of a weakly silicified deep sea chalk. Trans. Gulf Coast Assoc. Geol. Soc., 22:177-203.

Worsley, T. R., 1971. Calcareous nannofossil zonation of upper Jurassic and Lower Cretaceous sediments from the western Atlantic. In Farinaci, A. (Ed.), Proc. II Plankt. Conf. Roma: Rome (Tecnoscienza), 2:1301-1321.

Worzel, J. L., Bryant, W., et al., 1973. Init. Repts. DSDP, 10: Washington (U.S. Govt. Printing Office).

Date of Initial Receipt: March 15, 1983

Date of Acceptance: August 19, 1983

\section{APPENDIX}

Calcareous Nannofossil Species Considered in this Chapter (listed alphabetically by species epithets)

Parhabdolithus achylostaurion Hill, 1976

Corollithion achylosum (Stover) Thierstein, 1971

Ceratolithoides aculeus (Stradner) Prins and Sissingh in Sissingh, 1977

Lithraphidites acutum ssp. eccentricum Watkins n. ssp.

Braarudosphaera africana Stradner, 1961

Lithraphidites alatus Thierstein, 1972

Axopodorhabdus albianus (Black) Wind and Wise, 1976

Hayesites albiensis Manivit, 1971

Helicolithus anceps (Gorka) Noël, 1970

Crucicribrum anglicum Black, 1973

Retecapsa angustiforata Black, 1971

Rhagodiscus angustus (Stradner) Reinhardt, 1971

Vekshinella angusta (Stover) Verbeek, 1977

Reinhardtites anthophorus (Deflandre) Perch-Nielsen, 1968

Rhagodiscus asper (Stradner) Reinhardt, 1967

Watznaueria barnasae (Black) Perch-Nielsen, 1968

Nannoconus bermudezi Brönnimann, 1955

Cylindralithus biarcus Bukry, 1969

Flabellites biforaminis Thierstein, 1973

Reinhardtites biperforatus (Gartner) Shafik, 1979

Watznaueria biporta Bukry, 1969

Discorhabdus biradiatus (Worsley) Thierstein, 1973

Lithraphidites bollii (Thierstein) Thierstein, 1973

Watznaueria britannica (Stradner) Reinhardt, 1964

Nannoconus bronnimanni Trejo, 1959

Amphizygus brooksi Bukry, 1969

Nannoconus bucheri Brönnimann, 1955

Lithraphidites carniolensis Deflandre, 1963

Lucianorhabdus cayeuxii Deflandre, 1959

Cruciellipsis chiasta (Worsley) Thierstein, 1972

Haquis circumradiatus (Stover) Roth, 1978

Speetonia colligata Black, 1971

Nannoconus colomi (deLapparent) Kamptner, 1938

Prediscosphaera columnata (Stover) Manivit, 1971

Watznaueria communis Reinhardt, 1964

Micula concava (Stradner) Bukry, 1969

Cretarhabdus conicus Bramlette and Martini, 1964

Tetrapodorhabdus coptensis Black, 1971

Cylindralithus coronatus Bukry, 1969

Grantarhabdus coronoadventis (Reinhardt) Grün, 1975

Scampanella cornuta Forchheimer and Stradner, 1973

Stephanolithion crenulatum Stover, 1966

Cretarhabdus crenulatus Bramlette and Martini, 1964

Prediscosphaera cretacea (Arkhangelsky) Gartner, 1968

Cruciellipsis cuvillieri (Manivit) Thierstein, 1971

Arkhangelskiella cymbiformis Vekshina, 1959

Microrhabdulus decoratus Deflandre, 1959

Tetrapodorhabdus decorus (Deflandre) Wind and Wise, 1977

Micula decussata Vekshina, 1959

Cyclagelosphaera deflandrei (Manivit) Roth, 1973

Axopodorhabdus dietzmanni (Reinhardt) Wind and Wise, 1977
Laguncula dorotheae Black, 1971

Cribrosphaerella ehrenbergii (Arkhangelsky) Deflandre, 1952

Reinhardtites elegans (Gartner) Wise, 1983

Biscutum ellipticum (Gorka) Grün and Allemann, 1975

Corollithion ellipticum Bukry, 1969

Nannoconus elongatus Brönnimann, 1955

Parhabdolithus embergeri (Noël) Stradner, 1965

Zeugrhabdotus erectus (Deflandre) Stradner, 1965

Eiffelithus eximius (Stover) Perch-Nielsen, 1968

Reinhardtites fenestratus (Worsley) Thierstein in Roth and Thierstein, 1972

Eprolithus floralis (Stradner) Stover, 1966

Scapholithus fossilis Deflandre, 1954

Marthasterites furcatus (Deflandre) Deflandre, 1959

Tranolithus gabalus Stover, 1966

Cribrocorona gallica (Stradner) Perch-Nielsen, 1973

Ethmorhabdus gallicus Noël, 1965

Hexalithus gardetae Bukry, 1969

Nannoconus globulus Brönnimann, 1955

Eiffelithus gorkae Reinhardt, 1965

Quadrum gothicum (Deflandre) Prins and Perch-Nielsen in Manivit et al., 1977

Prediscosphaera grandis Perch-Nielsen, 1977

Lithastrinus grilli Stradner, 1962

Rucinolithus hayi Stover, 1966

Braarudosphaera hockwoldensis Black, 1973

Prediscosphaera honjoi Bukry, 1969

Sollasites horticus (Stradner, Adamiker, and Maresch) Black, 1968

Micrantholithus hoschulzi (Reinhardt) Thierstein, 1971

Bidiscus ignotus (Gorka) Lauer in Grün et al., 1972

Parhabdolithus infinitus (Worsley) Thierstein, 1974

Prediscosphaera intercisa (Deflandre) Shumenko, 1976

Markalius inversus (Deflandre) Bramlette and Martini, 1964

Rucinolithus irregularis Thierstein, 1972

Nannoconus kamptneri Brönnimann, 1955

Stephanolithion laffittei Noël, 1957

Diazmatolithus lehmani Noël, 1965

Reinhardtites levis Prins and Sissingh in Sissingh, 1977

Chiastozygus litterarius (Gorka) Manivit, 1971

Cretarhabdus loriei Gartner, 1968

Kamptnerius magnificus Deflandre, 1959

Cyclagelosphaera margereli Noël, 1965

Vagalapilla matalosa (Stover) Thierstein, 1973

Grantarhabdus meddii Black, 1971

Conusphaera mexicana Trejo, 1969

Staurolithites mielnicensis (Gorka) Perch-Nielsen, 1968

Lithastrinus moratus Stover, 1966

Micula mura (Martini) Bukry, 1963

Gartnerago nanum Thierstein, 1974

Quadrum nitidum (Martini) Prins and Perch-Nielsen in Manivit et al. (1977)

Gartnerago obliquum (Stradner) Noël, 1970

Calcicalithina oblongata (Worsley) Thierstein, 1971

Calculites obscurus (Deflandre) Prins and Sissingh in Sissingh (1977)

Micrantholithus obtusus Stradner, 1963

Ahmuellerella octoradiata (Gorka) Reinhardt, 1970

Tranolithus orionatus Stover, 1966

Calculites ovalis (Stradner) Prins and Sissingh in Sissingh (1977)

Broinsonia parca (Stradner) Bukry, 1969

Manivitella pemmatoidea (Deflandre ex Manivit) Thierstein, 1971

Darwinilithus pentarhethum Watkins n. gen, n. sp.

Chiastozygus platyrhethum Hill, 1976

Rhagodiscus plebeius Perch-Nielsen, 1968

Prediscosphaera ponticula (Bukry)

Braarudosphaera primula Black, 1973

Micula prinsii Perch-Nielsen, 1979

Lithraphidites quadratus Bramlette and Martini, 1964

Nannoconus quadriangulus Deflandre and Deflandre-Rigaud, 1962

Vekshinella quadriarculla (Noël) Rood et al., 1971

Hayesites radiatus (Worsley) Thierstein, 1976

Diadorhombus rectus Worsley, 1971

Braarudosphaera regularis Black, 1973

Rhagodiscus reightonensis (Taylor) Watkins, n. comb. 
Octocyclus reinhardtii (Bukry) Wind and Wise, 1977

Rhagodiscus reniformis Perch-Nielsen, 1973

Rhombolithion rhombicum (Stradner and Adamiker) Black, 1973 Zeugrhabdotus salillium (Noël) Rood et al., 1971

Retecapsa schizobrachiata (Gartner) Grün, 1975

Lithastrinus septenarius Forchheimer, 1972

Cylindralithus serratus Bramlette and Martini, 1964

Broinsonia signata (Noël) Noël, 1970

Corollithion signata Stradner, 1963

Arkangelskiella specillata Vekshina, 1959

Prediscosphaera spinosa (Bramlette and Martini) Gartner, 1968

Zygodiscus spiralis Bramlette and Martini, 1964

Rhagodiscus splendens (Deflandre) Verbeek, 1977

Nannoconus steinmannii Kamptner, 1931

Braarudosphaera stenorheta Hill, 1976

Prediscosphaera stoveri (Perch-Nielsen) Shafik and Stradner, 1971
Perchnielsenella stradneri (Perch-Nielsen) Watkins, n. comb.

Tegumentum stradneri Thierstein, 1972

Vagalapilla stradneri (Rood et al., 1971) Thierstein, 1973

Crucicribrum striatum (Stradner) Wise, 1983

Chiastozygus striatus Black, 1971

Watznaueria supracretacea (Reinhardt) Wind and Wise, 1977

Zeugrhabdotus theta (Black) Black, 1973

Helicolithus trabeculatus (Gorka) Verbeek, 1977

Quadrum trifidum (Stradner) Prins and Perch-Nielsen in Manivit et al., 1977

Nannoconus truitti Brönnimann, 1955

Eiffelithus turriseiffeli (Deflandre) Reinhardt, 1965

Ceratolithoides verbeekii Perch-Nielsen, 1979

Turbodiscus verenae Thierstein, 1973

Nannoconus wassalli Brönnimann, 1955

Rucinolithus wisei Thierstein, 1971 


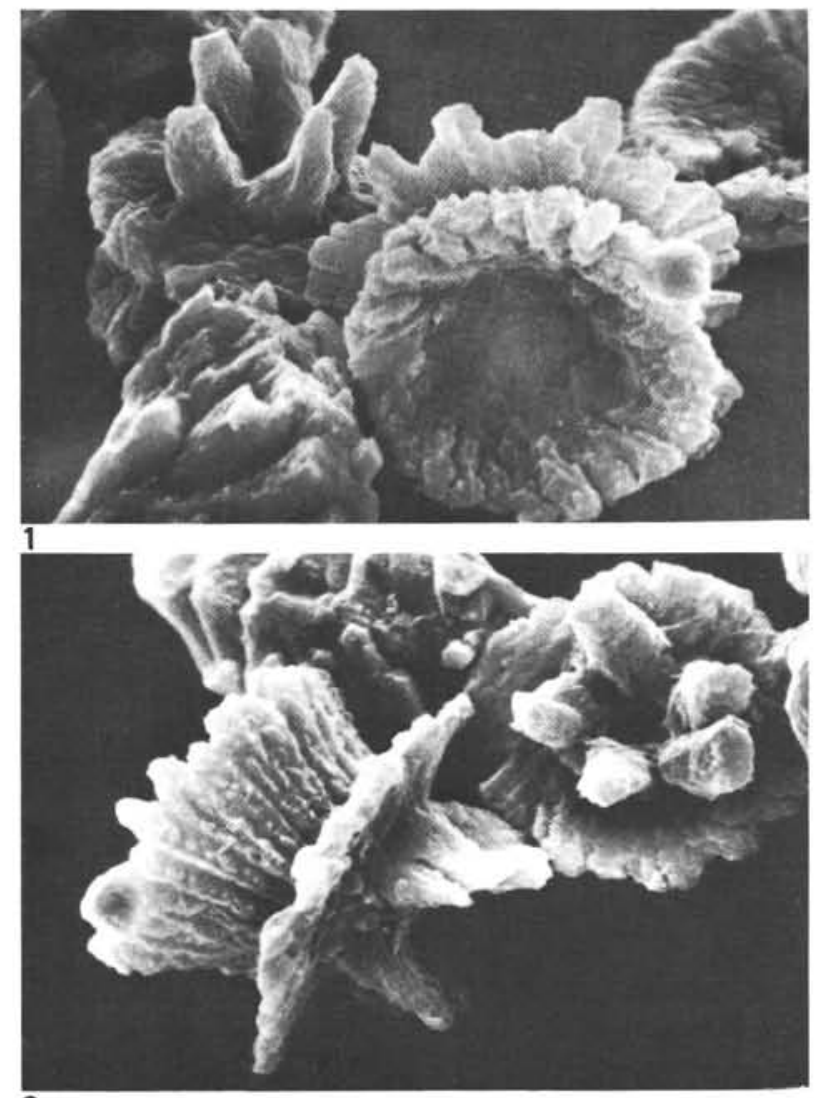

3

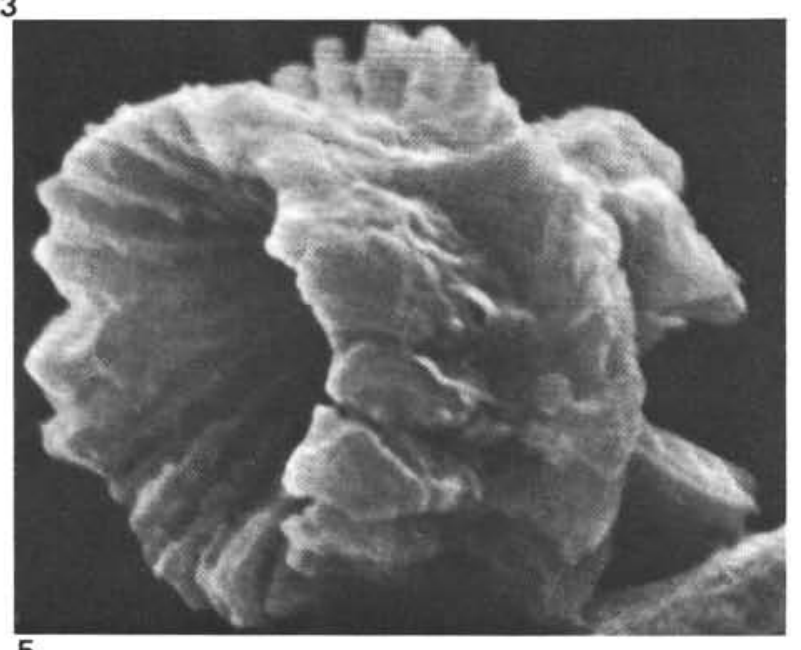

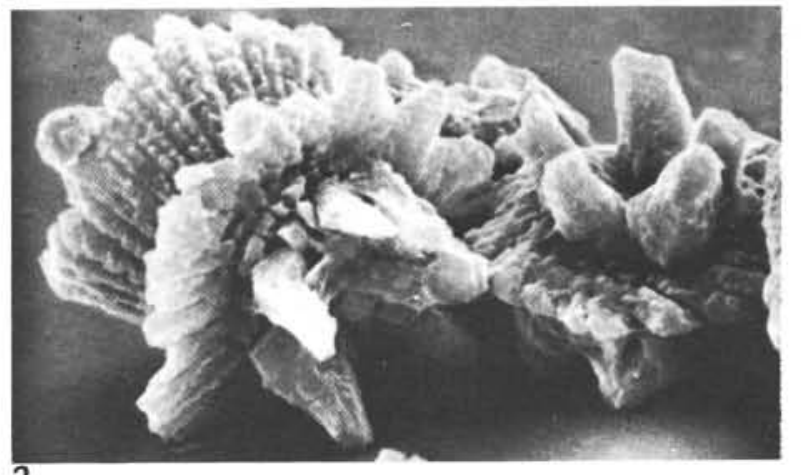

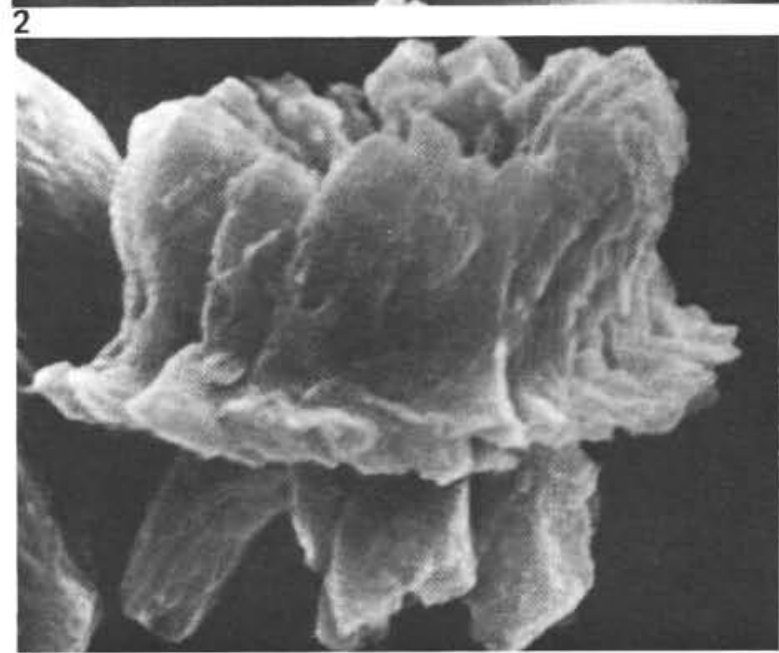

4

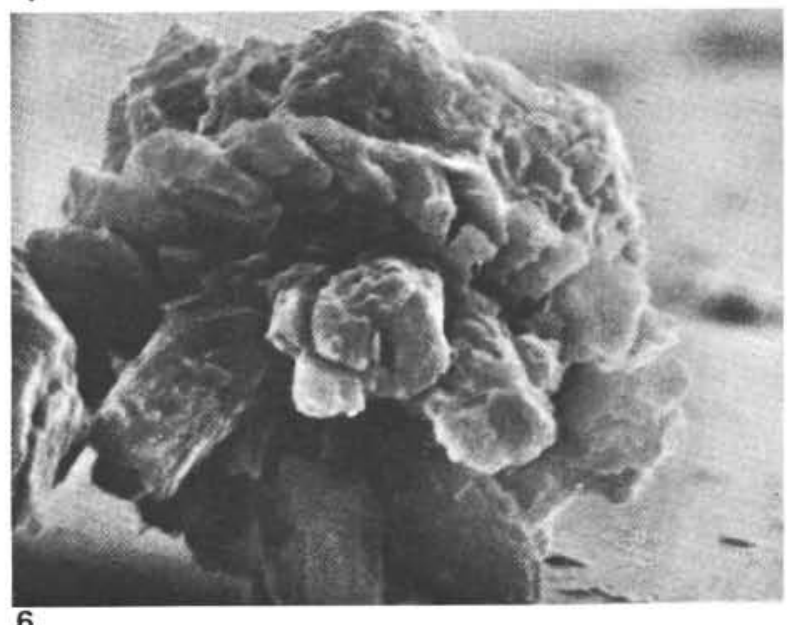

Plate 1. All specimens from Sample 540-33-1, 67-69 cm; Darwinilithus pentarhethum Watkins, n. sp. 1. Holotype (specimen on the right), distal view; paratype (specimen on the left), oblique proximal view (partially concealed), $\times 7000$. 2. Same specimens as in Figure 1; holotype specimen (left), oblique lateral view; paratype specimen (right), oblique distal view, $\times 7000$. 3. Same specimens as in Figure 1, holotype specimen (left), lateral view; paratype specimen (right), proximal view, $\times 7000$. 4. Lateral view, $\times 15,625$. 5. Same specimen as in Figure 4, oblique distal view, $\times 15,000$. 6. Same specimen as in Figure 4, oblique proximal view, $\times 15,000$. 

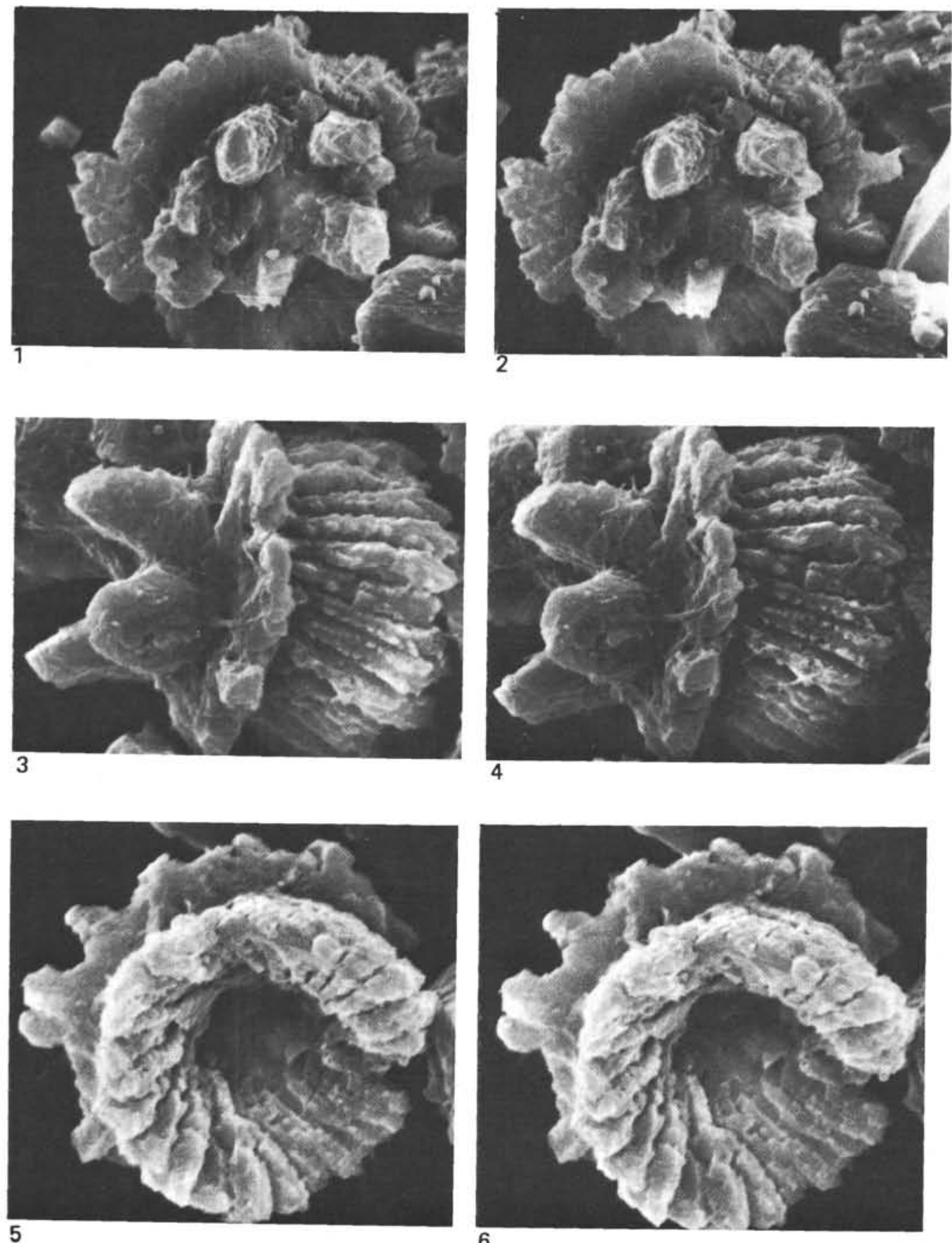

Plate 2. All specimens from Sample 540-33-1, 67-69 cm. Darwinilithus pentarhethum Watkins, n. sp. 1, 2. Stereopair, proximal view, $\times 8000$. 3, 4. Stereopair, lateral view, $\times 10,000$. 5, 6. Stereopair, distal view, $\times 10,000$. 

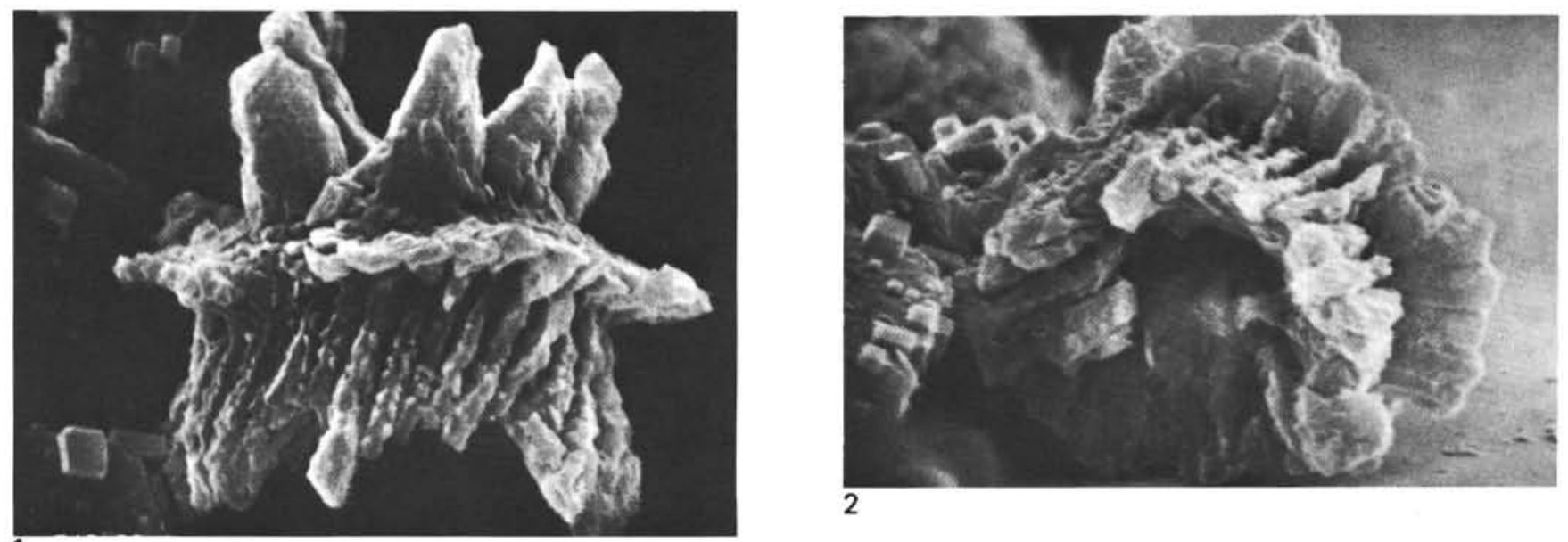

1

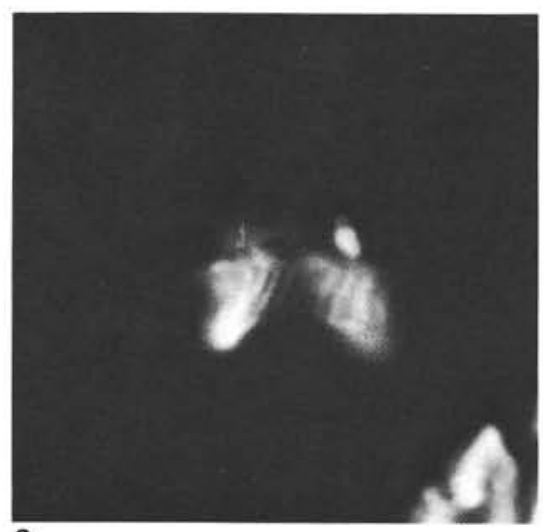

3

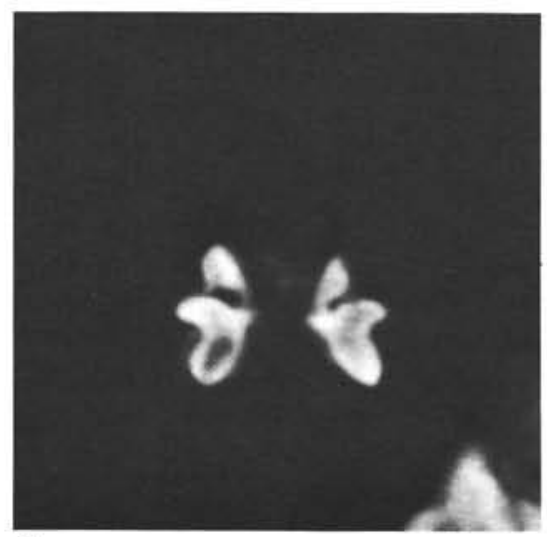

6

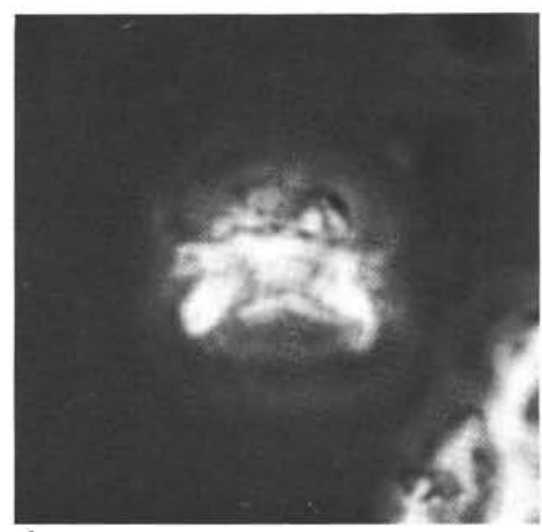

4

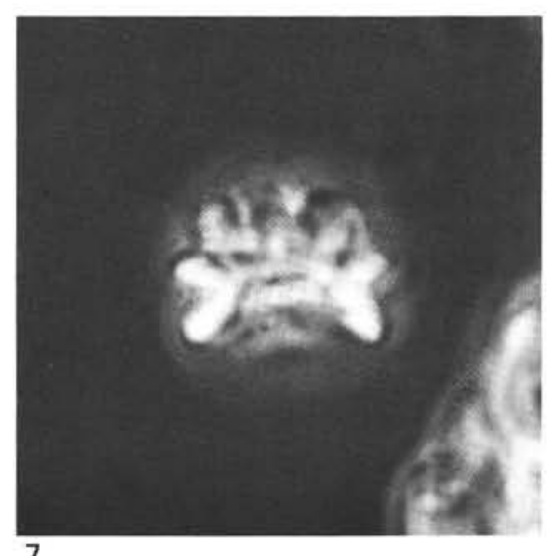

7

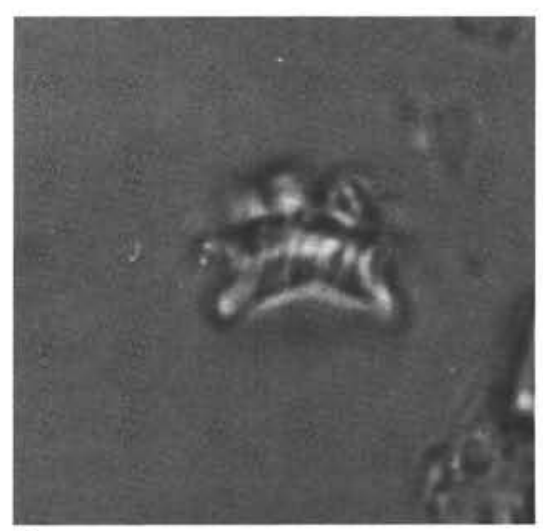

5

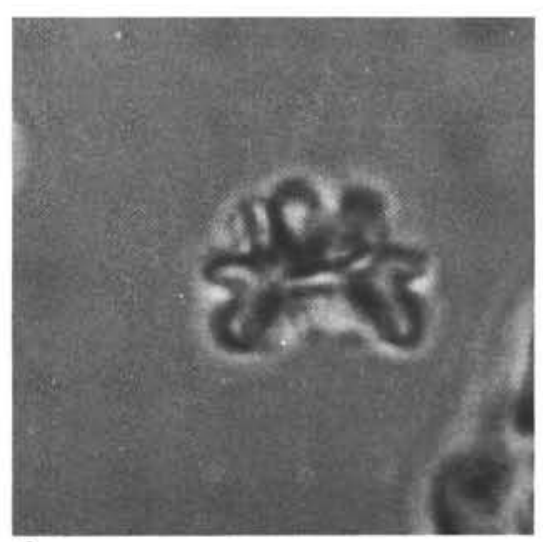

8

Plate 3. All specimens from Sample 540-3-1, 67-69 cm; Darwinilithus pentarhethum Watkins, n. sp. 1. Lateral view, $\times 10,000$. 2. Same specimen as in Figure 1, oblique distal view, $\times 9000$. 3-5. Light micrographs of lateral view, $\times 1700$, (3) cross-polarized light, (4) phase contrast, (5) transmitted light. 6-8. Light micrographs of lateral view, optical cross section, same specimen as in Figures $3-5, \times 1700,(6)$ cross-polarized light, (7) phase contrast, (8) transmitted light. 

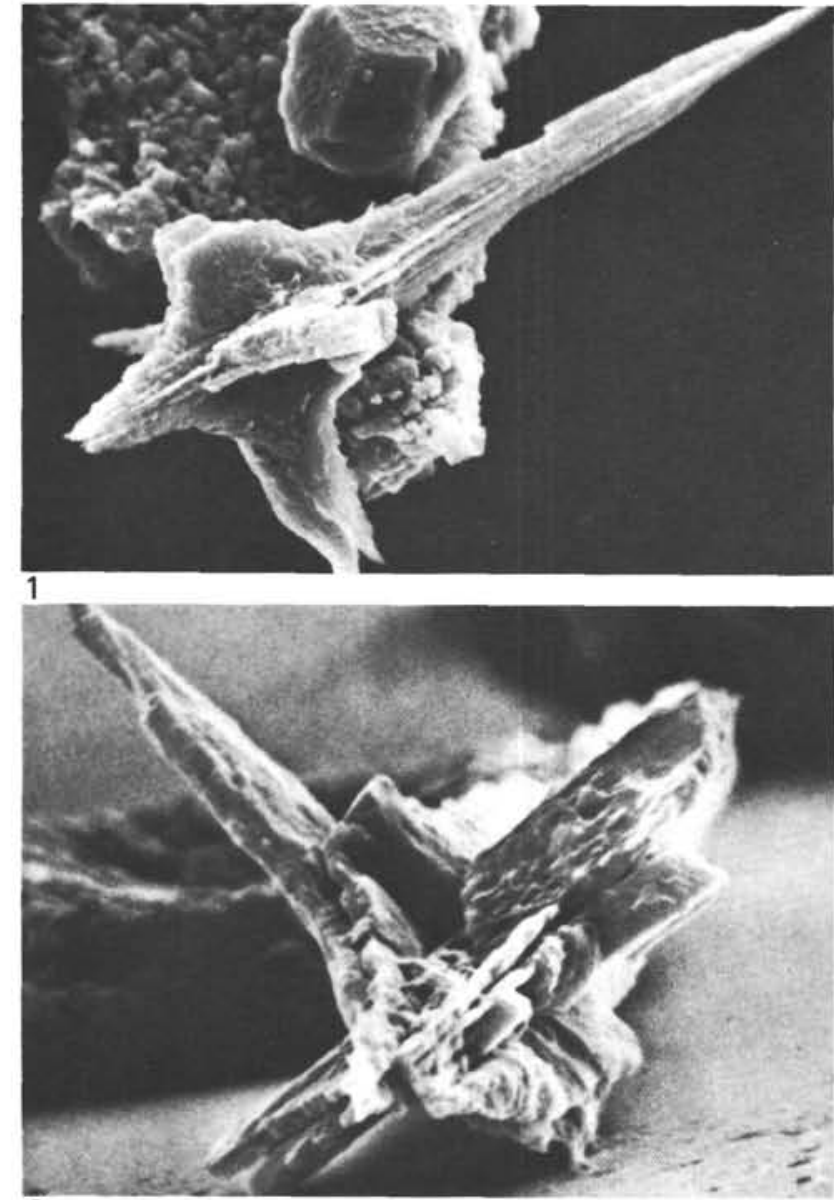

$\overline{3}$

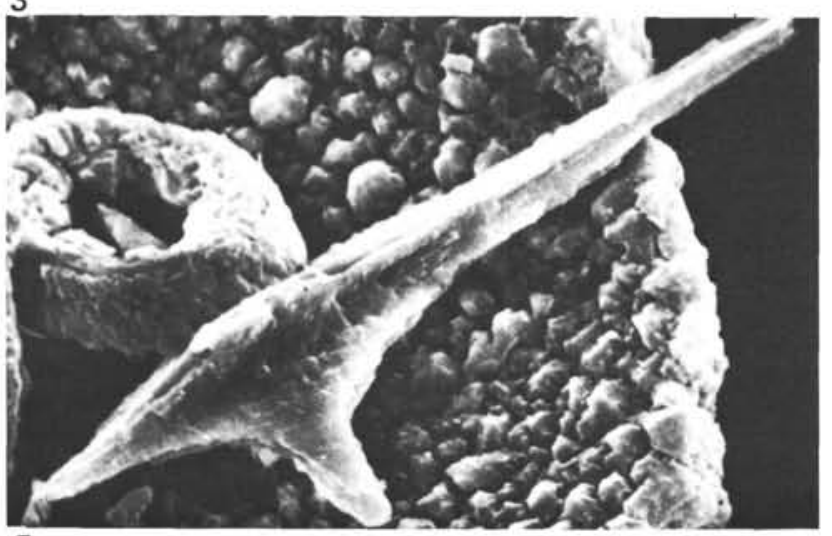

5

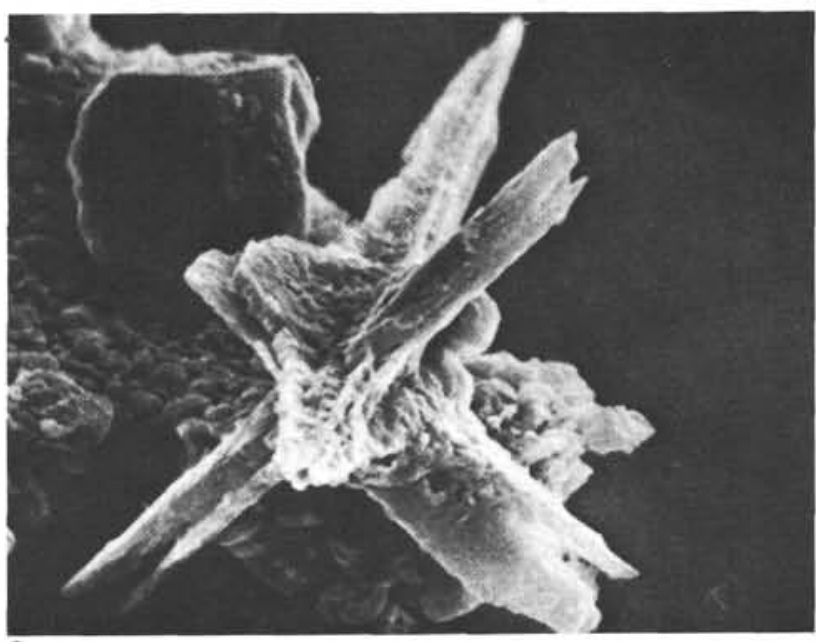

2

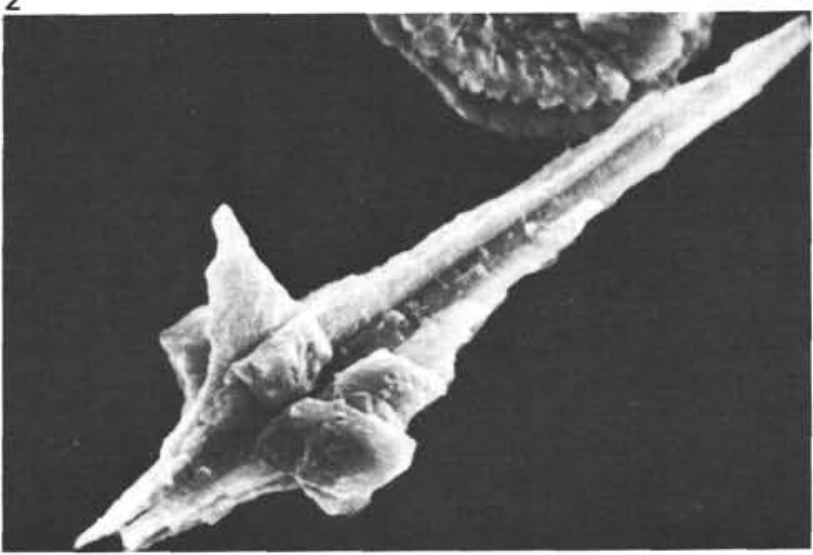

4

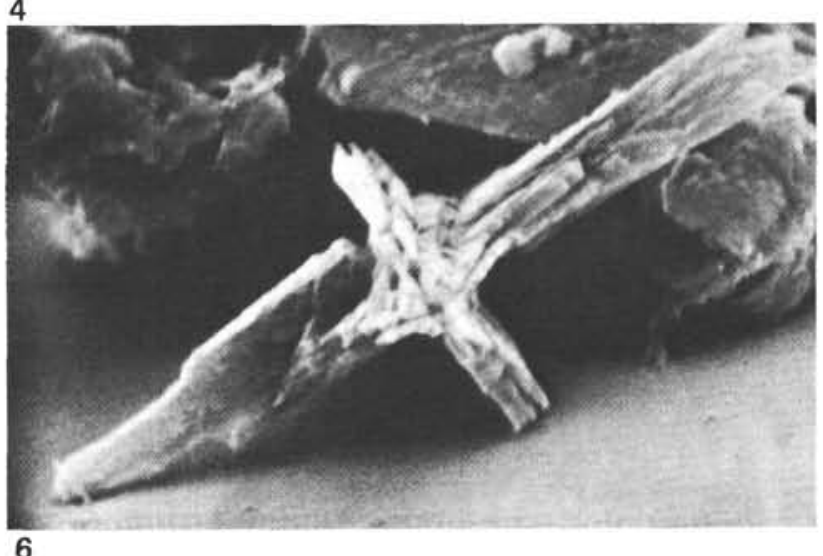

Plate 4. All specimens from Sample 540-33-1, 67-69 cm. Lithraphidites acutum ssp. eccentricum Watkins n. ssp. 1. Holotype, oblique lateral view, $\times 5000$. 2. Same specimen as in Figure 1, polar view, $\times 6800$, 3. Paratype, polar view, $\times 11,500$. 4. Same specimen as in Figure 3 , oblique lateral view, $\times 5500$. 5. Oblique lateral view, $\times 5750$. 6. Polar view, $\times 9500$. 


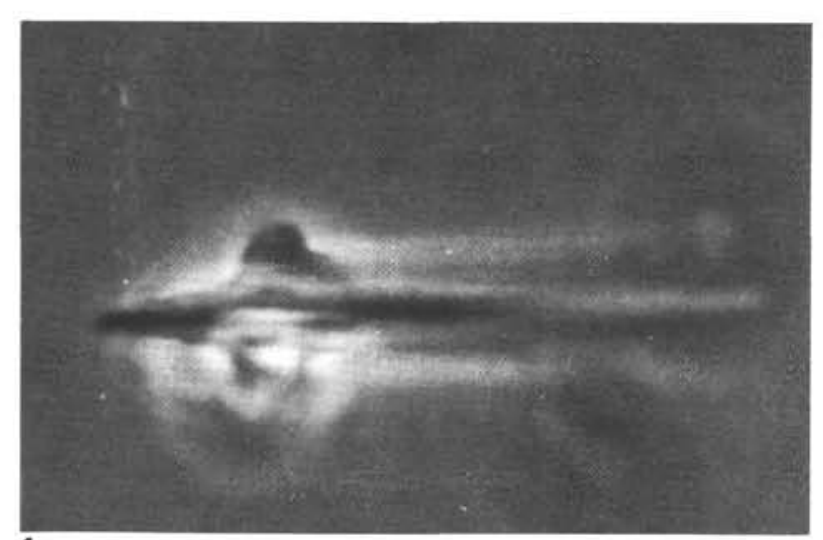

1

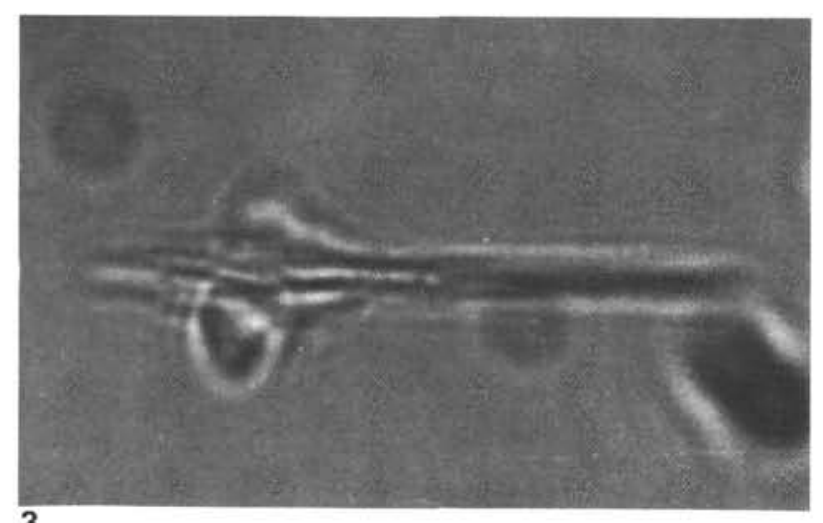

3

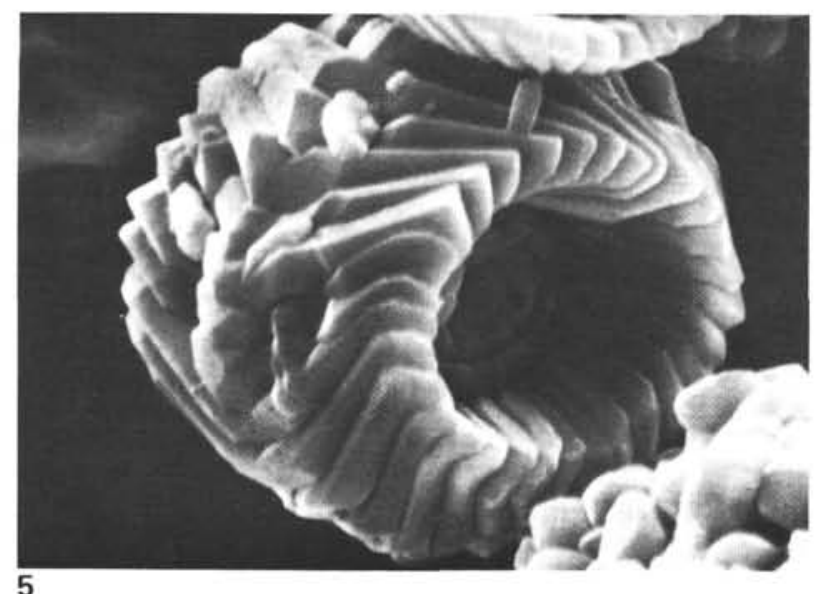

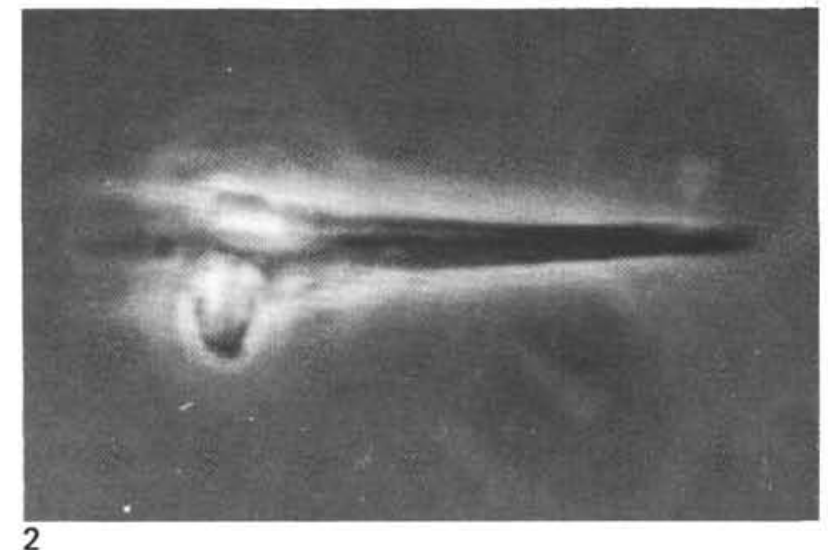

2

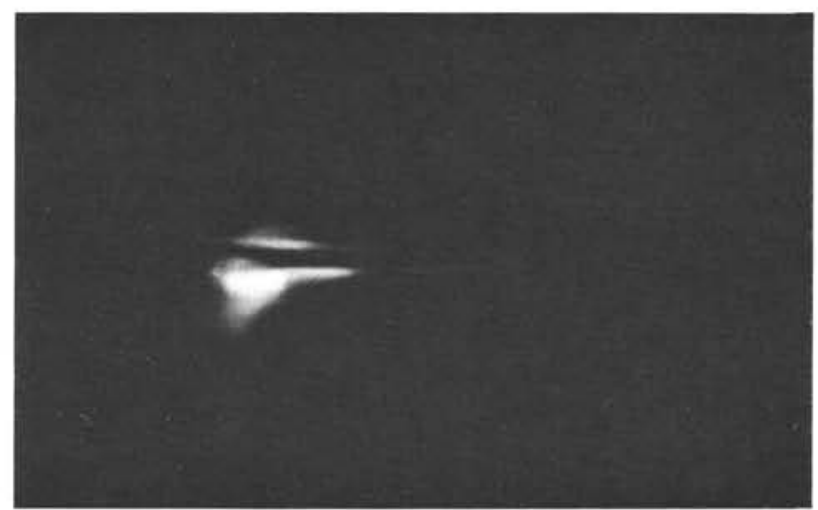

4

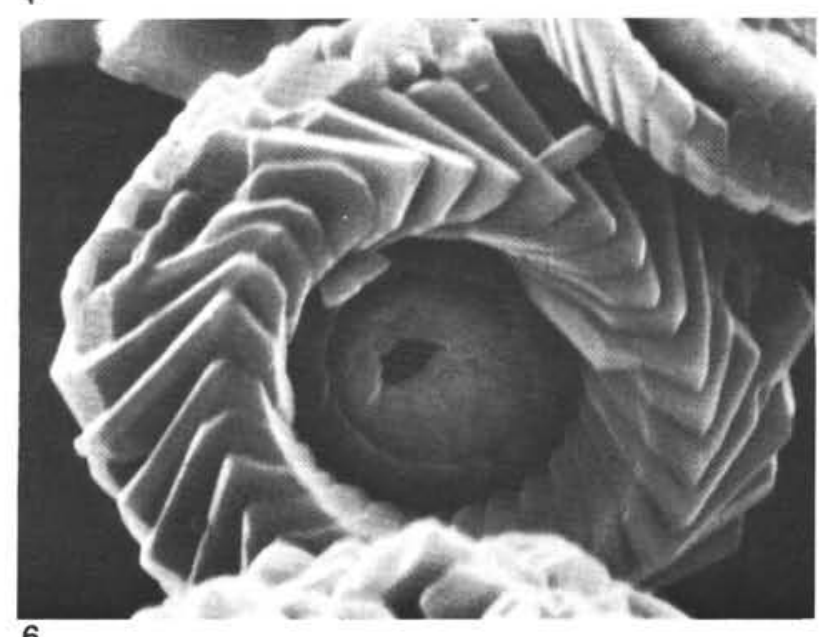

Plate 5. 1-4. Lithraphidites acutum ssp. eccentricum Watkins, n. ssp. Sample 540-33-1, 67-69 cm, (1) phase contrast, focused on the shorter pole of the specimen, $\times 2900$; (2) phase contrast, focused on the longer pole of the specimen, $\times 2900$; (3) transmitted light, $\times 2900$; (4) cross-polarized light with long axis of specimen parallel to direction of analyzer, $\times 2900$. 5, 6. Perchnielsenella stradneri (Perch-Nielsen) Watkins, n. comb. Sample 538A-21-2, 41-43 cm, (5) oblique proximal view, $\times 6950$; (6) proximal view, $\times 8220$, same specimen as in Figure 5 . 

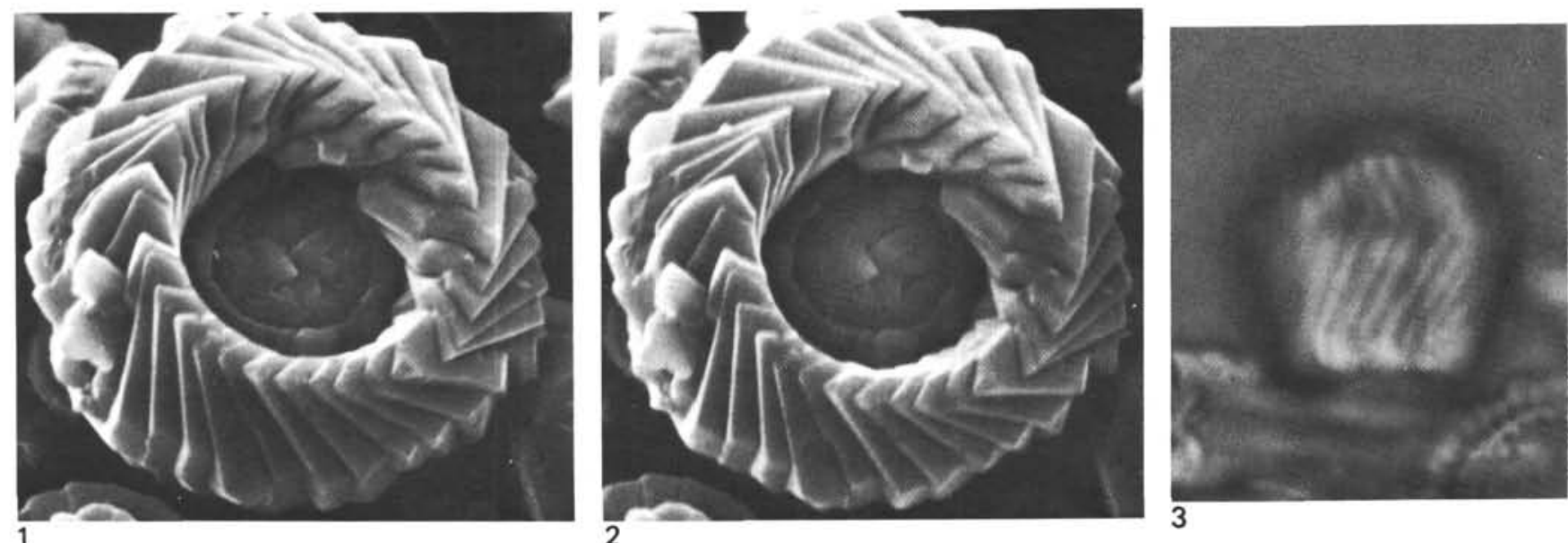
1

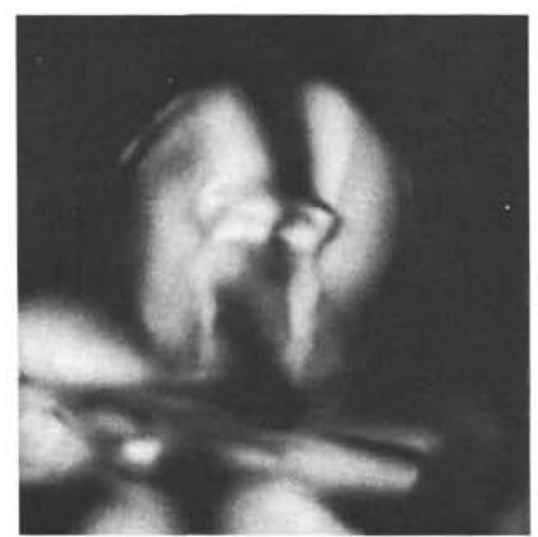

4

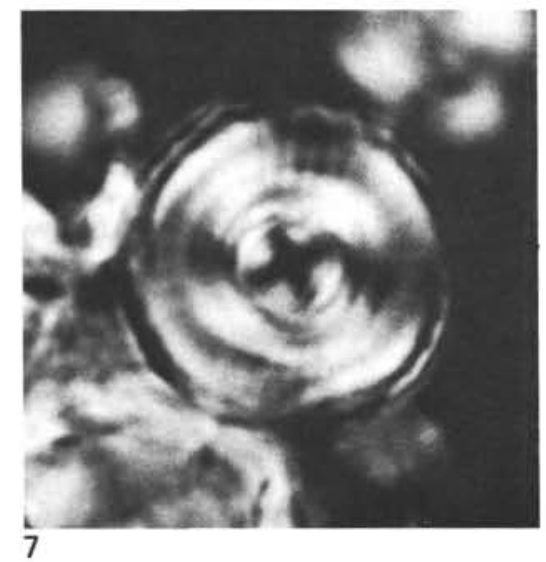

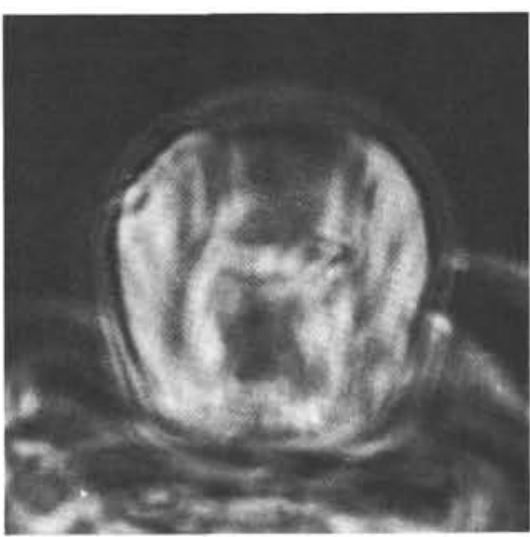

5

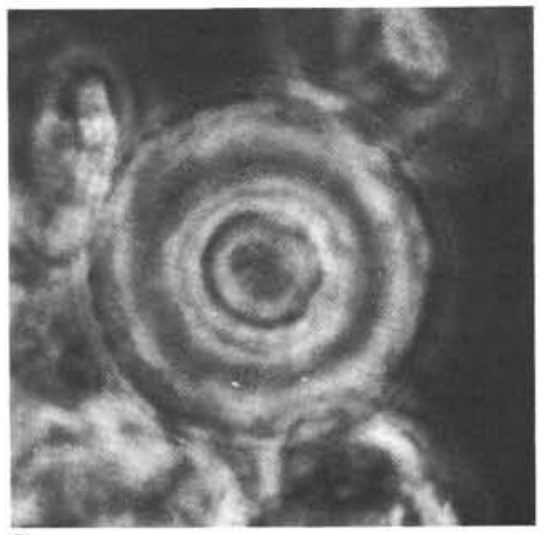

8

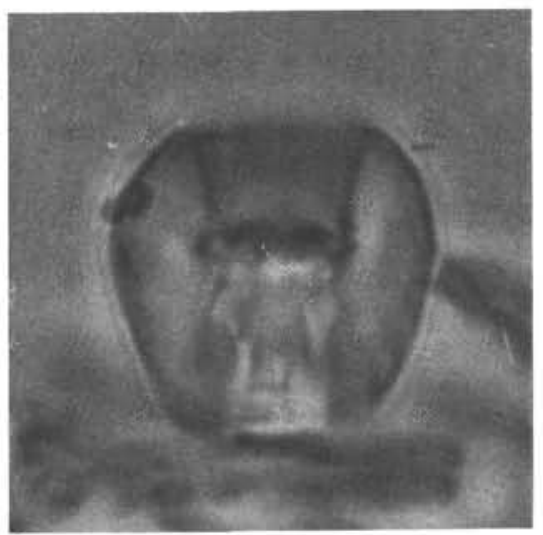

6

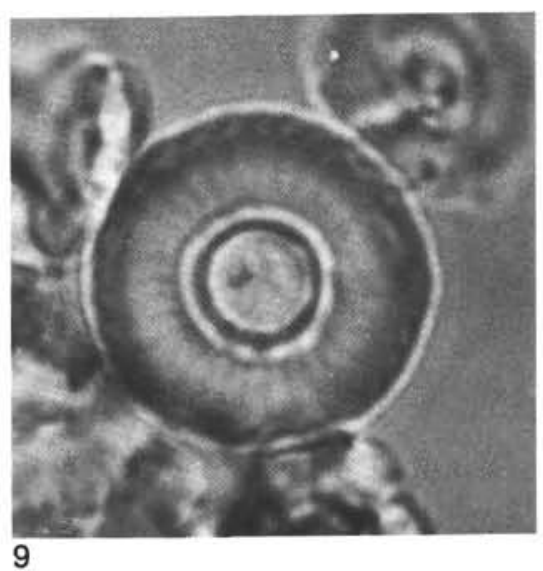

Plate 6. Perchnielsenella stradneri (Perch-Nielsen) Watkins, n. comb. 1, 2. Stereopair, proximal view, $\times 6350$, Sample 538A-21-2, 41-43 cm. 3 . Transmitted light, lateral view, $\times 3700$, Sample 538 A-21-3, 38-40 cm. 4-6. Light micrographs, lateral optical cross section, $\times 3700$, Sample 538A-21-3, 38-40 cm; (4) cross-polarized light; (5) phase contrast, (6) transmitted light. 7-9. Light micrographs of distal view, focused on central platform, $\times 4000$, Sample 538A-21-3, 38-40 cm; (7) cross-polarized light, (8) phase contrast, (9) transmitted light. 

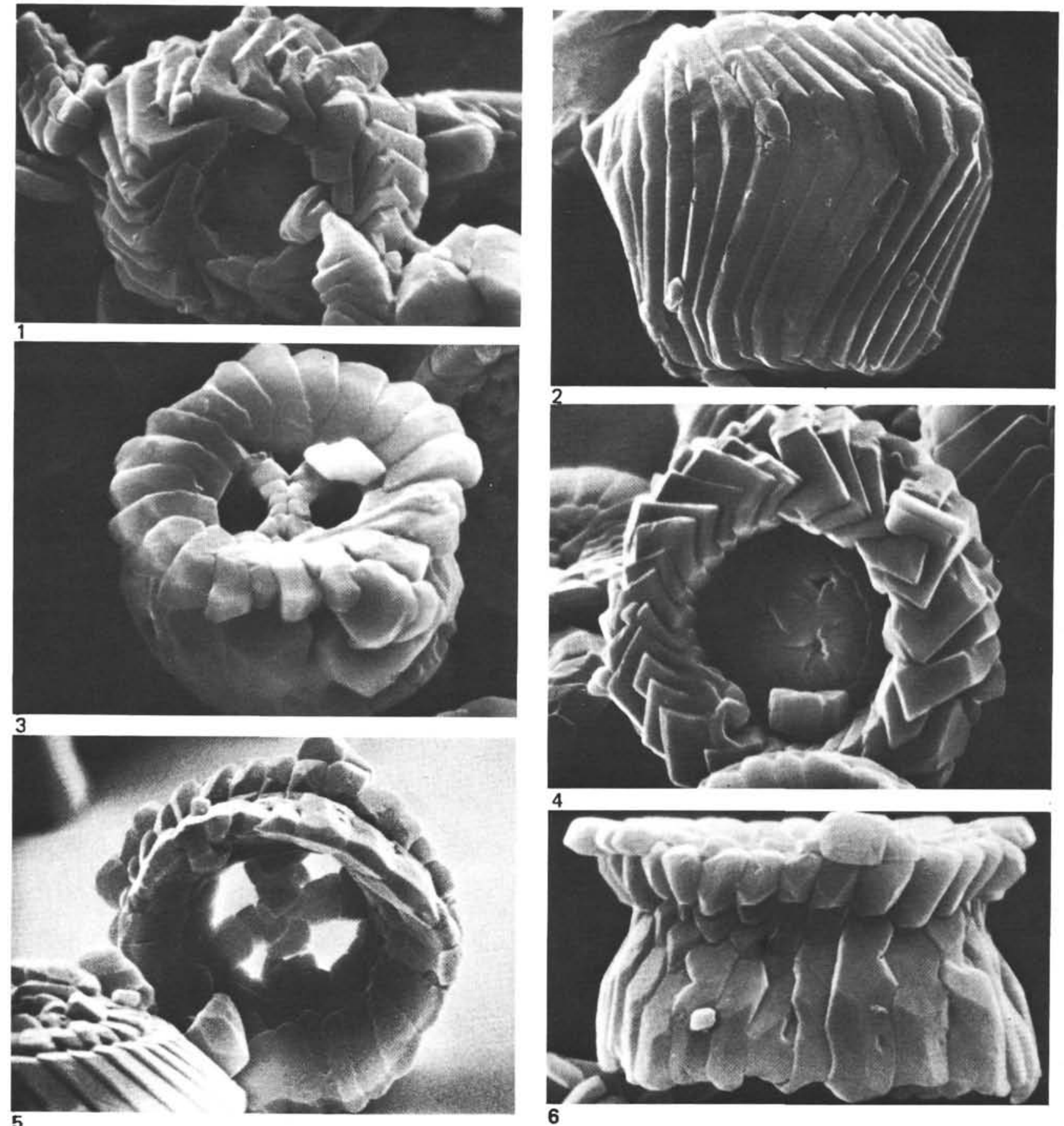

Plate 7. 1, 2, 4. Perchnielsenella stradneri (Perch-Nielsen) Watkins, n. comb.; (1) distal view, $\times 7300$, Sample 538A-21-2, 41-43 cm; (2) lateral view, $\times 7150$, Sample 538A-21-3, 38-40 cm; (4) proximal view, $\times 8900$, Sample 538 A-21-2, $41-43 \mathrm{~cm}$. 3. Cylindralithus biarcus Bukry, 1969, oblique proximal view, $\times 7400$, Sample $538 \mathrm{~A}-21-2,41-43 \mathrm{~cm}$. 5, 6. Cylindralithus coronatus Bukry, 1969. Sample 538A-21-4, 38-40 cm; (5) distal view,
$\times 10,000$; (6) lateral view, same specimen as in Figure 5. 